
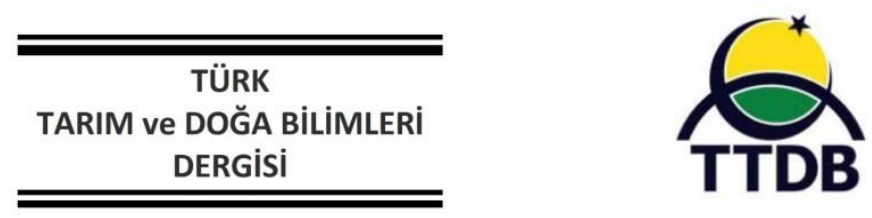

www.dergipark.gov.tr/turkjans

Araştırma Makalesi

\title{
Kahramanmaraş Yöresine Ait Yerel Ekmeklik Buğday Genotiplerinin Verim ve Fizyolojik Özellikler Yönünden İncelenmesi
}

\author{
Rukiye KARA ${ }^{1 *}$, Aydın AKKAYA ${ }^{2}$ \\ ${ }^{1}$ Doğu Akdeniz Geçit Kuşağı Tarımsal Araştırma Enstitüsü Müdürlüğü, Kahramanmaraş, Türkiye \\ ${ }^{2}$ Kahramanmaraş Sütçü İmam Üniversitesi, Ziraat Fakültesi, Tarla Bitkileri Bölümü, Kahramanmaraş, Türkiye \\ *Sorumlu Yazar: rkara46@gmail.com
}

\section{Geliş Tarihi: 06.09.2020 Düzeltme Geliş Tarihi: 21.10.2020 Kabul Tarihi: 22.10.2020}

Öz

Kahramanmaraş koşullarında, yerel ekmeklik buğday genotiplerinde fizyolojik karakterler yönünden mevcut varyasyonun belirlenmesi amacıyla yapılan bu çalışmada, 14 yerel ekmeklik buğday genotipi ve 3 standart çeşit materyal olarak kullanılmıştır. İncelenen özelliklerin çoğunda genotipler arasındaki farklar önemli bulunmuş, yaprak alanı (ZD:31 ve ZD:65), yaprak alan indeksi (ZD:31 ve ZD:65), özgül yaprak alanı (ZD:14-15, ZD:31 ve ZD:65) ve olgunlaşmadaki biyomas yönünden üstün özelliklere sahip yerel genotiplerin bulunduğu belirlenmiştir. Anasap yaprak alanında sapa kalkma başlangıcından çiçeklenme dönemine kadar olan sürede artış söz konusu olurken, yaprak alan indeksinde sapa kalkma başlangıcı ile çiçeklenme dönemi arasındaki sürede azalış söz konusu olmuştur. Dört yapraklı dönemde özgül yaprak alanı her iki yılda da birbirine yakın değerler göstermiş, sapa kalkma döneminde özgül yaprak alanı değeri ilk yıl düşerken ikinci yıl artmış, çiçeklenme döneminde ise her iki yılda da azalma meydana gelmiştir. Bu değişimlerde özellikler arası ilişkilerin her dönemde farklı ortaya çıkmasına sebep olmuştur. Tane verimi ile; sapa kalkma başlangıCı (ZD:31) ve çiçeklenme dönemindeki (ZD:65) ana sap yaprak alanı, dört yapraklı dönemdeki özgül yaprak alanı (ZD:14-15), sapa kalkma başlangıcındaki özgül yaprak alanı (ZD:31), tane dolum periyodu, yaprak alan süresi ve olgunlaşma dönemindeki biyomas arasındaki ilişkilerin olumlu ve önemli, sapa kalkma başlangıcındaki yaprak alan indeksi (ZD:31), çiçeklenme dönemindeki özgül yaprak alanı (ZD:65) arasındaki ilişkilerin olumsuz ve önemli olduğu belirlenmiştir.

Anahtar kelimeler: Yerel buğday genotipleri, verim, fizyolojik verim unsurları

\section{Investigation of Yield and Physiological Characteristics of Local Bread Wheat Genotypes in Kahramanmaras Region}

\begin{abstract}
This research was carried out during 2005-2007 crop seasons in Kahramanmaraş conditions to determine the variations for physiological traits of 14 wheat landraces and 3 commercial bread wheat varieties. Differences among genotypes for traits were generally significant and there were better landraces compared to commercial varieties for leaf area (ZD:31 and ZD:65), leaf area index (ZD:31 and ZD:65), specific leaf area (ZD:14-15, ZD:31 and ZD:65) and biomass at maturity. While there was an increase in the period from the beginning of the stem elongation to the flowering period in the main leaf area, there was a decrease in the period between the beginning of the stem elongation and the flowering period in the leaf area index. The specific leaf area showed similar values in both years in the four-leaf stage, while it decreased in the first year during the stem elongation, it increased in the second year. In the flowering period, there was a decrease in both years. These changes caused the relationships between properties to appear differently in each period. There were significant and positive relationships between grain yield and; leaf area of main stem at the beginning of stem elongation (ZD:31) and anthesis (ZD:65), specific leaf area at four-leaf (ZD:14-15), specific
\end{abstract}


leaf area at the beginning of stem elongation (ZD:31), grain filling period, leaf area duration, biomass at maturity. There were significant and negative relationships between grain yield and; leaf area index at the beginning of stem elongation (ZD:31), specific leaf area at the anthesis (ZD:65).

Key words: Wheat landraces, yield, physiological yield components

\section{Giriş}

Buğday bitkisi erken gelişme dönemlerinde, çevre faktörlerine ve uygulanan yetiştiricilik sistemlerine karşı az duyarlı iken, çiçeklenmeye doğru duyarlılık giderek artmaktadır (Fischer, 1985; Savin ve Slafer, 1991). Bu nedenle verimli koşullarda, erken gelişme dönemlerindeki yaprak alanının genetik olarak değiştirilmesi, verim üzerinde etkili olmayabilir. Buna karşılık toprak suyunun yetersiz olduğu, beslenme problemlerinin bulunduğu, büyüme sezonunun çok kısa olduğu elverişsiz çevre koşullarında, erken dönemde bitkinin hızlı büyüme özelliğine sahip olması verim yönünden yararlı olabilir (Richards, 1996a ve 1996b).

Buğday ıslah programlarında ele alınan seleksiyon kriterlerinden biri, çiçeklenme ile fizyolojik olgunluk arasındaki gelişme dönemini ifade eden tane dolum periyodudur. Araştırıcılar, buğdayda tanede biriken karbonhidratların büyük bir kısmının, çiçeklenme sonrası veya tane dolum dönemindeki fotosentezden kaynaklandığını ifade etmektedirler (Genç, 1977; Austin, 1982; Spiertz ve Vos, 1985). Verim oluşumundaki bu önemine bağlı olarak, buğdayda tane dolum periyodunu konu alan çok sayıda araştırmaya rastlamak mümkündür. $\mathrm{Bu}$ araştırmaların çoğunda, kışlık buğday genotipleri arasında tane dolum periyodu yönünden önemli farkların bulunduğu, tane dolum periyodunun özellikle yüksek sıcaklıklar ve nem yetersizliği tarafından sınırlandığı ve bu karakterin, tane ağırlığı ve verimle olumlu ve önemli ilişki gösterdiği belirlenmiştir (Wiegand ve ark., 1981; Gebeyehou ve ark., 1982a; Hunt ve ark., 1991; Housley ve Ohm, 1992).

Tane dolum periyodu esnasındaki potansiyel fotosentez, çiçeklenmedeki yaprak alan indeksinin bir yansımasıdır. Bitki toplam yaprak alanının, bitki tarafından kaplanmış toprak alanına oranı yaprak alan indeksi olarak adlandırılmakta (Coombs ve ark., 1987), verim unsurlarından birisi olarak değerlendirilmekte ve çiçeklenme sonrası asimilasyon yönünden çok önem olduğu belirtilmektedir (Austin, 1982; Richards, 1983; Woodruft ve Tonks, 1983; Waddington ve ark., 1986; Major ve ark., 1992).

Yaprak alan indeksi ve yaprakların yeşil kalma süresinin bir fonksiyonu olan yaprak alan süresi, çiçeklenme sonrası fotosentez ve verim farklılıklarının açıklanmasında temel unsurlardan biri olarak kabul edilmektedir (Warrington ve ark., 1977; Steduto ve ark., 1986; Shuting, 1994). Çukurova koşullarında yaprak alanı ve sürekliliği bakımından çeşitler arasında önemli farkların olduğu, bu farklılığın başak tane verimine yansıdığı ve bayrak yaprakta alt yapraktan daha önemli olduğu, bayrak yaprak alanı büyük ve bayrak yaprak alan süresi uzun olan çeşitlerin başak veriminin de yüksek çıktığı ifade edilmektedir (Tiryakioğlu ve Koç, 2007). Yaprak alan indeksinin herhangi bir gelişme dönemindeki değerinden çok, yaprak alan süresinin önemli olduğu, özellikle tane doldurma döneminde yeşil alanını daha uzun süre koruyabilen çeşitlerin genellikle daha yüksek verimli oldukları, bunun özellikle stres koşullarında daha önemli olduğu belirtilmektedir (Jenner ve Rathjen, 1975; Reynolds, 2002). Yaprak alan süresi ile tane verimi arasındaki ilişkilerin olumlu ve çok önemli olduğuna dikkat çeken araştırıcılar, yaprak alanı süresinin uzatılmasının, tane veriminin artırılmasında çok etkili bir faktör olduğunu vurgulamışlardır (Borojevic ve Williams, 1982).

Hasat indeksinin teorik üst sınıra yaklaşmış olduğu yörelerde, bundan böyle sağlanacak verim artışları daha çok biyoması artırmakla mümkün olabileceği, yeni buğday çeşitlerinin zaten optimum boy uzunluğu sınırları içerisinde oldukları, bitki boyunu daha da kısaltarak verim artışı sağlamanın pek mümkün olamayacağı belirtilmektedir (Slafer ve ark., 2000). Batı Avustralya'da Rht genini taşıyan bodur hatlarda, bazı eski ve yeni buğday çeşitlerinde, sap ve başağın büyüme hızı bakımından çeşitler arasında farklılık olduğu, başak büyüme hızının, yeni çeşitlerde eski çeşitlerden, uzun boylu hatlara göre bodur hatların daha yüksek olduğu görülmüştür. Başak/sap kuru madde oranının, terminal başakçık oluşumundan çiçeklenmeye kadar olan dönemde \% 20-50 arasında değiştiği, bu oranın çiçeklenmede, yeni çeşitlerde eski çeşitlerden, bodur hatlarda uzun boylu hatlardan daha yüksek olduğu saptanmıştır (Siddique ve ark. 1989a).

Ekmeklik buğdayda verim artışı, toplam kuru madde veriminde (biyomas) fazla bir değişiklik olmadan hasat indeksinin artırılması ile sağlanmıştır (Cox ve ark., 1988; Austin ve ark., 1989; Slafer ve Andrade 1993; Aparicio ve ark., 2002). 1962-1988 arasında CIMMYT buğdaylarında hasat indeksi artarken, biyomasın hemen hemen değişikliğe uğramadığı (Sayre ve ark., 1997), ancak 
hasat indeksi yönünden \% 60 olarak ifade edilen teorik üst sınıra (Austin ve ark., 1980) çok yaklaşıldığı için bundan sonraki verim potansiyeli artışları açısından, biyomasda sağlanacak artışların önemli olacağı belirtilmektedir. Çukurova koşullarında yapılan çalışmada hasat indeksindeki değişimlerin verimdeki değişimlere paralel bir şekilde gerçekleştiği, buna karşılık biyomas değişimlerinin kararlı olmadığı, ayrıca hasat indeksi ile verim arasındaki ilişkinin de, biyomas ile verim arasındaki ilişkiye göre daha kararlı ve güçlü olduğu belirtilmiştir. Sonuçta, verimdeki ilerlemenin biyomastaki artıştan çok hasat indeksindeki artıştan kaynaklandığı tespit edilmiştir (Kuşcu, 2006).

Buğday ıslahında sürekli yeni gen kaynaklarına gereksinim duyulmaktadır. Doğal olarak uzun yıllar sonunda ortaya çıkmış olan yerel genotipler, ıslah programlarında varyasyonu sağlayabilmek yönünden çok önemli potansiyel gen kaynakları olarak karşımıza çıkmaktadır (Biesandz, 1990; Kınacı, 1993; Zencirci ve ark., 1993). Ülkemizdeki yerel genotiplerin fizyolojik özelliklerinin ortaya konulması ileride yapılacak olan buğday yetiştiriciliği ve ıslahı çalışmaları bakımından büyük önem taşımaktadır. Yerel materyaller üzerinde ıslahta kullanılabilecek fizyolojik özelliklerin de ortaya çıkarılması gerekmektedir. $\mathrm{Bu}$ nedenle bu çalışmada, Kahramanmaraş yöresindeki yerel ekmeklik buğday genotipleri ele alınarak, fizyolojik özellikler yönünden genotipler arasındaki varyasyonlar belirlenmeye çalışılmıştır.

\section{Materyal ve Yöntem}

Araştırma, 2005-07 yılları arasında Doğu Akdeniz Geçit Kuşağı Tarımsal Araştırma Enstitüsü Müdürlüğünün deneme arazisinde yürütülmüştür. Çalışmanın yürütüldüğü Kahramanmaraş ili Türkiye'nin Doğu-Akdeniz Bölgesinde, $37^{\circ} 38^{\prime}$ kuzey enlem ve $36^{\circ} 37^{\prime}$ doğu boylam arasında yer almakta olup, rakımı 568 m'dir. Araştırmada kullanılan yerel çeşitlerin kayıt numaraları, yerel adı ve toplandığı yer Çizelge 3.1'de verilmiştir. Kahramanmaraş koşullarında yaygın olarak ekilen Seri-82, Golia ve Adana-99 ekmeklik buğday çeşitleri ise standart çeşit olarak kullanılmıştır.

Çizelge 1. Denemede kullanılan genotiplerin kayıt numaraları, yerel adı ve toplandığı bölge

\begin{tabular}{cll}
\hline Kayıt numaraları & Yerel adı & Toplandığı bölge \\
\hline 4 & Polatlı Yazlığı & Ortaören / Ekinözü \\
5 & AlaBuğday & Boylu / Çağlayancerit \\
11 & AlaBuğday & Bostanlı / Andırın \\
13 & Ak Buğday & Doluca / Türkoğlu \\
19 & Nurhak Buğdayı & Düzbağ / Çağlayancerit \\
21 & Kırmızı Buğday & Alaçık / Çağlayancerit \\
24 & Polatlı Yazlığı & Ambarcık / Elbistan \\
31 & Beyaz Buğday & Boylu / Çağlayancerit \\
33 & Elbistan Yazlığı & Tepebaşı / Elbistan \\
35 & Ofis Yazlığı & Çoğulhan / Afşin \\
48 & Ankara Yazlığı & Tarlacık / Afşin \\
49 & Ziron Yazlığı & Büyük Kızılcık / Göksun \\
50 & Yerli Buğday & Büyük Kızılcık / Göksun \\
51 & Göksun Buğdayı & Büyük Kızılcık / Göksun \\
Seri-82 & Standart çeşit & \\
Golia & Standart çeşit & \\
Adana-99 & Standart çeşit & \\
\hline
\end{tabular}

Çizelge 2 den görüldüğü gibi, Kahramanmaraş'da uzun yıllar ortalamasına göre yıllık yağış miktarı 660.0 mm'dir. Araştırmanın yürütüldüğü birinci ve ikinci ürün yıllarındaki yıllık toplam yağışlar sırasıyla 645.3 ve $522.2 \mathrm{~mm}$ olmuştur. Uzun yıllar ortalamasına göre, birinci ürün yılında 14.7, ikinci ürün yılında ise $137.8 \mathrm{~mm}$ daha az yağış düşmüştür. Yağışın miktarı yanında, vejetasyon periyodu içerisindeki dağılımı da yıllar arasında önemli farklılık göstermiştir. Özellikle çimlenme, çıkış ve ilk büyümenin gerçekleştiği dönem olan Kasım-Aralık aylarında, yağış miktarının ikinci ürün yılında uzun yıllar ortalamasından daha düşük olduğu görülmektedir. Bunun sonucu olarak ikinci deneme yılında çimlenme ve çıkış problemi gözlenmiştir. Ocak ve Şubat aylarında birinci yılda, ikinci yıldan ve uzun yıllar ortalamasından oldukça yüksek miktarda yağış meydana gelmiştir (Çizelge 2). Buna karşılık, bitkilerin generatif gelişme gösterdikleri Mart, Nisan ve Mayıs aylarındaki yağış miktarı bakımından ise ikinci ürün yılı birinci ürün yılından 
ve uzun yıllar ortalamasına göre daha üstün olmuştur. Uzun yıllar ortalamasına göre, Kahramanmaraş'da yıllık ortalama sıcaklık 12.5 ${ }^{\circ} C^{\prime}$ dir. Araştırmanın yürütüldüğü ürün yıllarındaki yıllık ortalama sıcaklık değerleri ilk yıl 13.5, ikinci yıl $13.2{ }^{\circ} \mathrm{C}$ olmuştur. Her iki ürün yılı da uzun yıllar ortalamasına göre, daha yüksek yıllık ortalama sıcaklığa sahip olmuştur. Yörede uzun yıllar ortalamasına göre yıllık ortalama nispi nem \% 62.2'dir. Araştırmanın birinci ve ikinci ürün yıllarındaki yıllık nispi nem değerleri ise, sırasıyla \% 65.8 ve $\% 59.1$ olmuştur.

Çizelge 2. Deneme yılları ve uzun yıllar ortalamasına ait bazı iklim verileri

\begin{tabular}{|c|c|c|c|c|c|c|c|c|c|}
\hline \multirow[b]{2}{*}{ Aylar } & \multicolumn{3}{|c|}{ Yağış (mm) } & \multicolumn{3}{|c|}{ Sicaklık $\left({ }^{\circ} \mathrm{C}\right)$} & \multicolumn{3}{|c|}{ Nispi nem (\%) } \\
\hline & 1.YII & 2. YII & $\begin{array}{c}\text { Uzun yıllar } \\
\text { (1983-2005) }\end{array}$ & 1.YII & 2. YII & $\begin{array}{l}\text { Uzun } \\
\text { yıllar }\end{array}$ & 1.YII & 2. YII & $\begin{array}{l}\text { Uzun } \\
\text { yillar }\end{array}$ \\
\hline Kasım & 69.6 & 77.0 & 99.9 & 10.8 & 10.3 & 10.9 & 66.4 & 60.6 & 64.4 \\
\hline Aralık & 93.5 & 1.1 & 124.8 & 8.4 & 6.8 & 6.2 & 76.2 & 53.3 & 69.0 \\
\hline Ocak & 102.0 & 63.1 & 115.7 & 3.8 & 4.9 & 5.2 & 72.0 & 63.5 & 70.8 \\
\hline Şubat & 232.7 & 133.6 & 105.8 & 6.9 & 7.8 & 6.2 & 70.1 & 71.2 & 65.3 \\
\hline Mart & 96.8 & 99.9 & 96.1 & 11.7 & 11.4 & 10.3 & 66.1 & 57.9 & 60.7 \\
\hline Nisan & 36.6 & 87.8 & 71.9 & 17.0 & 13.3 & 15.5 & 62.5 & 57.6 & 59.1 \\
\hline Mayıs & 14.1 & 58.9 & 40.9 & 21.9 & 23.4 & 20.4 & 55.0 & 59.1 & 55.8 \\
\hline Haziran & - & 0.8 & 4.9 & 27.4 & 27.5 & 25.0 & 58.4 & 49.8 & 52.4 \\
\hline Toplam & 645.3 & 522.2 & 660.0 & & & & & & \\
\hline Ortalama & & & & 13.5 & 13.2 & 12.5 & 65.8 & 59.1 & 62.2 \\
\hline
\end{tabular}

Her iki ürün yılında da deneme yeri toprakları tınlı tekstürdedir. Deneme yeri topraklarının 0-30 $\mathrm{cm}$ ve $30-60 \mathrm{~cm}^{\prime}$ de $\mathrm{pH}^{\prime}$ sı sırasıyla ilk yılda 7.68 ile 7.46, ikinci yılda ise 7.67 ile 7.57, kireç oranı ise ilk yıl \% 23.95 ile 24.71, ikinci yıl ise \%23.00 ile 24.90 sınırları arasında bulunmuştur. 0$30 \mathrm{~cm}$ ve $30-60 \mathrm{~cm}$ 'de bitkilere elverişli fosfor miktarı sırasıyla ilk yılda 6.08 ile $4.30 \mathrm{~kg} / \mathrm{da}$, ikinci yılda 4.85 ile $3.68 \mathrm{~kg} / \mathrm{da}$, elverişli potasyum miktarı ilk yıl 107.64 ile 104.16 kg/da, ikinci yıl 93.75 ile $76.38 \mathrm{~kg} / \mathrm{da}$ arasında belirlenmiştir. Organik madde oranları ilk yılda 0-30 cm'de \% 1.44 olurken 30-60 cm'de \% 1.09; ikinci yılda ise 0-30 cm'de \% 1.06 olurken $30-60$ cm'de \% 0.85 olarak bulunmuştur.

Araştırma, tesadüf blokları deneme desenine göre 4 tekrarlamalı olarak kurulmuştur. Ekim, $8.30 \mathrm{~m}$ uzunluğundaki parsellere, $20 \mathrm{~cm}$ aralıkla 6 sıralı parsel mibzeri ile metrekareye 550 tane gelecek şekilde ilk yıl 11 Kasım 2005 tarihinde ikinci yıl, 21 Kasım 2006 tarihinde yapılmıştır. Her iki yılda da ekimle birlikte 20-20-0 kompoze gübresi kullanılarak, dekara $8 \mathrm{~kg} \mathrm{~N}$ ve $8 \mathrm{~kg} \mathrm{P}_{2} \mathrm{O}_{5}$ olacak şekilde gübreleme yapılmıştır. Ayrıca, ilk yıl kardeşlenme dönemi sonunda; ikinci yıl ise kardeşlenme ve sapa kalkma dönemlerinde 5'er $\mathrm{kg} / \mathrm{da}$ olmak üzere toplam $10 \mathrm{~kg} / \mathrm{da} N$ (\%33 $\mathrm{NH}_{4} \mathrm{NO}_{3}$ formunda) uygulanmıştır. Her iki deneme yılında da sulama yapılmamış, yabancı ot mücadelesi yabancı ot ilacı kullanılarak yapılmıştır.

Bitki gelişim dönemleri Zadoks Skalası (ZD) dikkate alınarak belirlenmiştir. Bitkilerin yaprak alanı, sapa kalkma başlangıcında (ZD:31) ve çiçeklenme döneminde (ZD:65) olmak üzere 10 bitkinin ana sap üzerindeki bütün yaprakların alanı ölçülerek yapılmıştır. Birinci yılda bütün yaprakların eni ve boyu ölçülmüş ve 0.75 katsayısı ile çarpılarak yaprak alanı belirlenmiştir. İkinci yıl ise, AM-300 yaprak alanı ölçme cihazı kullanılarak anasapa ait yaprak alanları belirlenmiştir. Yaprak alan indeksi, sapa kalkma başlangıcı (ZD:31) ve çiçeklenme (ZD:65) dönemlerinde, LAI-2000 Plant Canopy Analyser aleti kullanılarak ölçülmüştür. Alet ile parseldeki bitkilerin üzerinden bir ölçüm ve daha sonra toprak yüzeyinden iki ölçüm alınmıştır. Tüm ölçümler, yansıyan ışık etkisini elemine etmek amacıyla güneşin ufka yakın olduğu zamanlarda (sabah veya akşamüstü) yapılmış ve 90 o’lik görüntü kapakları kullanılmıştır. Özgül yaprak alanı bitkiler dört yapraklı döneme (ZD:14-15) geldiğinde, sapa kalkma başlangıcında (ZD:31) ve çiçeklenme (ZD:65) dönemlerinde 10 bitkinin ana sapı üzerindeki bütün yaprakların alanları ölçülmüş, yapraklar $70^{\circ} \mathrm{C}^{\prime}$ de 48 saat süreyle kurutulduktan sonra tartılarak yaprak kuru ağırlığı belirlenmiştir. Yaprak alanının yaprak kuru ağırlığına oranlanmasıyla özgül yaprak alanı belirlenmiştir. Bu özellikler dışında tane dolum periyodu, olgunlaşma dönemindeki biyomas, tane verimi ve hasat indeksi gibi özelliklerde incelenmiştir. Yaprak alan süresi ise aşağıda belirtilen formile göre belirlenmiştir.

Yaprak alan süresi (gün) $=\left(\mathrm{L}_{1}+\mathrm{L}_{2}\right) / 2 \times\left(T_{2}-\mathrm{T}_{1}\right)$ formülüyle belirlenmiştir. $L_{1}$ ve $L_{2} ;$ sırasıyla çiçeklenme ve fizyolojik olgunluk dönemlerindeki yaprak alan indeksleri, $\mathrm{T}_{1}$; ekimden çiçeklenme tarihine kadar geçen süre gün olarak, $\mathrm{T}_{2}$; ekimden olgunlaşmaya kadar geçen süre gün olarak belirlenmiştir. 
Karakterlere ait veriler SAS (SAS, 1999) paket programı kullanılarak varyans analizine tabi tutulmuş, genotip ortalamalarının karşılaştırılmasında Duncan çoklu karşılaştırma testi kullanılmıştır.

\section{Bulgular ve Tartışma Anasap yaprak alanı}

Anasap yaprak alanı yönünden genotipler arasındaki farklar, sapa kalkma başlangıcında ilk yıl ve yılların birlikte analizine göre önemli olurken ( $P \leq$ 0.01), ikinci yıl önemsiz olmuş, çiçeklenme döneminde ise ikinci yılda $(P \leq 0.01)$ ve yılların birlikte analizinde $(P \leq 0.05)$ istatistiki olarak önemli olurken ilk yıl önemsiz olmuştur. Anasap yaprak alanı değeri yılXgenotip interaksiyonu yönünden sapa kalkma başlangıcında istatistiki olarak önemsiz olurken, çiçeklenme döneminde önemli $(P \leq 0.01)$ olmuştur.

Birinci yıl en yüksek sapa kalkma başlangıcındaki anasap yaprak alanı $74.81 \mathrm{~cm}^{2} /$ bitki ile Golia çeşidinden, en düşük anasap yaprak alanı değeri $43.36 \mathrm{~cm}^{2} /$ bitki ile Polatlı Yazlığı-24 genotipinden elde edilmiştir. İki yıllık ortalama verilere göre, sapa kalkma başlangıcındaki en yüksek anasap yaprak alanı değeri $79.45 \mathrm{~cm}^{2} /$ bitki ile Seri-82 çeşidinden, en düşük yaprak alanı değeri Polatlı Yazlığı-24 genotipinden, $50.74 \mathrm{~cm}^{2} /$ bitki değeri ile elde edilmiştir (Çizelge 3). Buğday genotipleri arasında yaprak alanı yönünden önemli farkların bulunduğu Puckridge (1971), Spiertz ve ark. (1971), Ashraf (2000) ve Giunta ve ark. (2008) tarafından da tespit edilmiştir. Moraques ve ark. (2006), 52 yerel buğday çeşidi ile yaptıkları çalışmada, sapa kalkma başlangıcındaki anasap yaprak alanı değerlerinin 51.8-56.3 $\mathrm{cm}^{2}$ arasında değiştiğini belirlemişlerdir. Anasap yaprak alanı ortalaması ilk yıl $60.17 \mathrm{~cm}^{2} /$ bitki iken, ikinci yıl bu değer $73.38 \mathrm{~cm}^{2} /$ bitki olmuştur. Mart-Nisan aylarındaki yağış miktarı, ikinci ürün yılında birinci yıldan ve uzun yıllar ortalamasından daha yüksek olmuştur. Sıcaklık koşullarının da uygun gitmesi sonucu, gelişme daha hızlı olmuş ve yaprak alanı ikinci yılda daha yüksek olmuştur.

Çizelge 3. Yerel ve standart ekmeklik buğday genotiplerinde sapa kalkma başlangıcı ve çiçeklenme dönemindeki anasap yaprak alanına ilişkin ortalama değerler

\begin{tabular}{|c|c|c|c|c|c|c|}
\hline \multirow[t]{2}{*}{ Genotipler } & \multicolumn{3}{|c|}{$\begin{array}{c}\text { Sapa kalkma başlangıcındaki anasap } \\
\text { yaprak alanı (cm²/bitki) }\end{array}$} & \multicolumn{3}{|c|}{$\begin{array}{l}\text { Çiçeklenme dönemindeki anasap yaprak } \\
\text { alanı }\left(\mathrm{cm}^{2} / \mathrm{bitki}\right)\end{array}$} \\
\hline & 1. $Y_{\text {III** }}$ & 2. YII & Ort. ** & 1. YII & 2. YII & Ort. ${ }^{*}$ \\
\hline Polatlı Yazlığı-4 & $63.28 \mathrm{abcd}$ & 75.72 & $69.50 \mathrm{abc}$ & 71.76 & $64.60 \mathrm{~d}$ & $68.18 \mathrm{~d}$ \\
\hline Alabuğday-5 & 58.14 bcde & 70.15 & $64.14 \mathrm{bcd}$ & 84.71 & $83.87 \mathrm{bcd}$ & $84.29 \mathrm{abcd}$ \\
\hline Alabuğday-11 & $48.33 \mathrm{de}$ & 70.84 & $59.58 \mathrm{~cd}$ & 82.41 & $78.20 \mathrm{bcd}$ & $80.30 \mathrm{bcd}$ \\
\hline Ak Buğday-13 & 58.96 bcde & 71.94 & $65.45 a b c$ & 81.69 & $87.69 \mathrm{bcd}$ & $84.69 \mathrm{abcd}$ \\
\hline Nurhak Buğdayı-19 & 57.77 bcde & 73.09 & $65.43 a b c$ & 79.31 & $89.87 \mathrm{bcd}$ & $84.59 \mathrm{abcd}$ \\
\hline Kırmızı Buğday-21 & 57.12 bcde & 66.34 & $61.73 \mathrm{bcd}$ & 73.02 & $95.81 \mathrm{abc}$ & $84.42 \mathrm{abcd}$ \\
\hline Polatlı Yazlığı-24 & $43.36 \mathrm{e}$ & 58.12 & $50.74 \mathrm{~d}$ & 87.85 & $78.51 \mathrm{bcd}$ & $83.18 \mathrm{abcd}$ \\
\hline Beyaz Buğday-31 & $65.05 a b c$ & 86.47 & $75.76 \mathrm{ab}$ & 70.57 & $95.93 a b c$ & $83.25 \mathrm{abcd}$ \\
\hline Elbistan Yazlığı-33 & $64.58 a b c$ & 67.61 & $66.09 a b c$ & 66.22 & $90.40 \mathrm{bcd}$ & $78.31 \mathrm{bcd}$ \\
\hline Ofis Yazlığı-35 & $62.80 \mathrm{abcd}$ & 68.82 & $65.81 \mathrm{abc}$ & 84.71 & $69.43 \mathrm{~cd}$ & $77.07 \mathrm{bcd}$ \\
\hline Ankara Yazlığı-48 & 55.28 cde & 86.15 & $70.71 \mathrm{abc}$ & 75.09 & $80.25 \mathrm{bcd}$ & $77.67 \mathrm{bcd}$ \\
\hline Ziron Yazlığı-49 & 57.07 bcde & 70.54 & $63.81 \mathrm{bcd}$ & 70.37 & $75.79 \mathrm{~cd}$ & $73.08 \mathrm{~cd}$ \\
\hline Yerli Buğday-50 & 55.49 cde & 65.57 & $60.53 \mathrm{~cd}$ & 55.69 & $87.45 \mathrm{bcd}$ & $71.57 \mathrm{~cd}$ \\
\hline Göksun Buğdayı-51 & 57.21 bcde & 85.44 & $71.32 \mathrm{abc}$ & 79.41 & $104.99 a b$ & $92.20 \mathrm{ab}$ \\
\hline Adana-99 & $73.01 \mathrm{ab}$ & 69.24 & $71.12 \mathrm{abc}$ & 83.15 & $91.92 \mathrm{bcd}$ & $87.53 \mathrm{abc}$ \\
\hline Seri-82 & $70.65 \mathrm{abc}$ & 88.26 & $79.45 \mathrm{a}$ & 77.79 & $120.52 \mathrm{a}$ & $99.15 \mathrm{a}$ \\
\hline Golia & $74.81 \mathrm{a}$ & 73.09 & $73.95 a b c$ & 80.52 & $89.18 \mathrm{bcd}$ & $84.85 \mathrm{abcd}$ \\
\hline Ortalama & $60.17 b$ & $73.38 \mathrm{a}$ & 66.77 & $76.72 b$ & $87.32 \mathrm{a}$ & 82.02 \\
\hline
\end{tabular}

** $\mathrm{P}<0.01$ düzeyinde önemli, * $\mathrm{P}<0.05$ düzeyinde önemli

Çiçeklenme dönemi anasap yaprak alanı ikinci yılda Seri-82 çeşidinde en yüksek olmuş, Polatlı Yazlığı-4 genotipi ise en düşük anasap yaprak alanına sahip genotip olmuştur (Çizelge 3 ). iki yıllık ortalamalara göre, en yüksek yaprak alanı değeri $99.15 \mathrm{~cm}^{2}$ ile Seri-82 çeşidinden, en düşük değer $68.18 \mathrm{~cm}^{2}$ ile Polatlı Yazlığı-4 genotipinden elde edilmiştir. Moraques ve ark. (2006), yerel buğday çeşitlerinde çiçeklenme dönemindeki anasap yaprak alanı değerlerinin 55.5-64.6 cm $\mathrm{cm}^{2}$ arasında değiştiğini belirlemişlerdir. Çiçeklenme dönemindeki anasap yaprak alanı değerleri, genotiplerin ortalaması olarak ilk yıl $76.72 \mathrm{~cm}^{2}$, ikinci yıl $87.32 \mathrm{~cm}^{2}$ olmuştur. Denemenin ilk yılında elde edilen değerlerin genel olarak ikinci yılda elde edilen değerlerden daha düşük olduğu 
görülmektedir. Çiçeklenme döneminin gerçekleştiği Nisan-Mayıs aylarındaki sıcaklık ve yağış miktarı, ikinci ürün yılında birinci yıldan ve uzun yıllar ortalamasından daha yüksek olmuştur. Buna bağlı olarak ikinci yıldaki yaprak alanı değerleri yüksek olmuştur. Ekmeklik buğday genotiplerinin sap başına yaprak sayısı veya yaprak gelişme oranının, iklim faktörlerine göre değiştiği belirtilmiştir (Öztürk, 1996).
Sapa kalkma başlangıcından çiçeklenme dönemine kadar olan sürede anasap yaprak alanında her iki yılda ve yılların ortalaması olarak incelendiğinde artış söz konusu olmuştur (Şekil 1). Yaprak alan artışı ilk yılda \% 27.51, ikinci yılda \% 19.00 ve ortalamalar yönünden bakıldığında ise \% 22.84 civarında

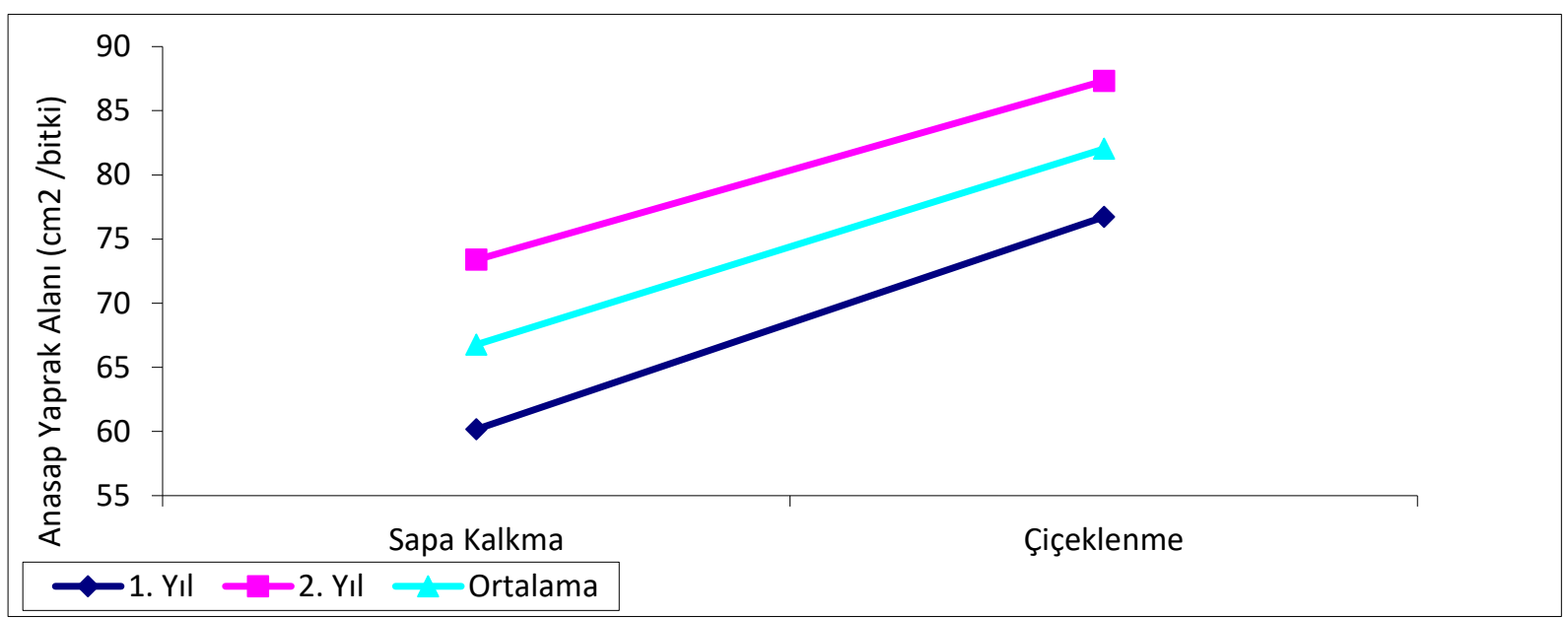

Şekil 1. Sapa kalkma başlangıcından çiçeklenme dönemine kadar anasap yaprak alanında meydana gelen değişimler

\section{Yaprak alan indeksi}

Sapa kalkma dönemindeki yaprak alan indeksi bakımından genotipler arasındaki farklar sadece ikinci yıl önemli olurken $(P \leq 0.05)$, ilk yılda, yılların birlikte analizinde, yıllar arasındaki farklar ve yılXgenotip interaksiyonu yönünden önemsiz bulunmuştur. Çiçeklenme dönemindeki yaprak alan indeksi bakımından genotipler arasındaki farklar ilk yılda, ikinci yılda, yılların birlikte analiz edilmesinde ve yılXgenotip interaksiyonu bakımından önemsiz bulunurken yıllar arasındaki farklar önemli ( $P \leq$ 0.01 ) bulunmuştur.

Çizelge 4. Yerel ve standart ekmeklik buğday genotiplerinde sapa kalkma başlangıcı ve çiçeklenme dönemindeki yaprak alan indeksine ilişkin ortalama değerler

\begin{tabular}{|c|c|c|c|c|c|c|}
\hline \multirow{2}{*}{ Genotipler } & \multicolumn{3}{|c|}{ Sapa kalkma başlangıcı yaprak alan indeksi } & \multicolumn{3}{|c|}{ Çiçeklenme dönemindeki yaprak alan indeksi } \\
\hline & 1.YII & 2. YII* & Ort. & 1. Yוl & 2. YII & Ort. \\
\hline Polatlı Yazlığı-4 & 6.048 & $6.108 \mathrm{ab}$ & 6.078 & 4.750 & 5.115 & 4.933 \\
\hline Alabuğday-5 & 6.058 & $4.490 \mathrm{bc}$ & 5.274 & 4.205 & 4.660 & 4.433 \\
\hline Alabuğday-11 & 4.943 & $5.683 \mathrm{abc}$ & 5.313 & 3.633 & 5.088 & 4.360 \\
\hline Ak Buğday-13 & 5.908 & $5.073 a b c$ & 5.490 & 4.803 & 4.518 & 4.660 \\
\hline Nurhak Buğdayı-19 & 5.223 & $4.523 \mathrm{bc}$ & 4.873 & 4.405 & 4.455 & 4.430 \\
\hline Kırmızı Buğday-21 & 5.573 & $5.635 a b c$ & 5.604 & 3.540 & 4.838 & 4.189 \\
\hline Polatlı Yazlığı-24 & 5.678 & 6.638 a & 6.158 & 3.768 & 4.823 & 4.295 \\
\hline Beyaz Buğday-31 & 6.005 & $4.813 \mathrm{bc}$ & 5.409 & 4.413 & 4.463 & 4.438 \\
\hline Elbistan Yazlığı-33 & 6.035 & $5.723 a b c$ & 5.879 & 4.163 & 4.288 & 4.225 \\
\hline Ofis Yazlığı-35 & 4.820 & $5.648 a b c$ & 5.234 & 4.805 & 4.920 & 4.863 \\
\hline Ankara Yazlığı-48 & 6.090 & $6.660 \mathrm{a}$ & 6.375 & 4.340 & 4.870 & 4.605 \\
\hline Ziron Yazlığı-49 & 6.610 & $5.808 a b c$ & 6.209 & 4.370 & 4.443 & 4.406 \\
\hline Yerli Buğday-50 & 5.263 & $5.915 a b c$ & 5.589 & 5.088 & 4.688 & 4.888 \\
\hline Göksun Buğdayı-51 & 5.238 & $4.845 \mathrm{bc}$ & 5.041 & 3.520 & 5.068 & 4.294 \\
\hline Adana-99 & 5.338 & $5.533 a b c$ & 5.435 & 4.748 & 5.103 & 4.925 \\
\hline Seri-82 & 5.250 & $4.255 c$ & 4.753 & 4.508 & 5.015 & 4.761 \\
\hline Golia & 5.710 & $4.500 \mathrm{bc}$ & 5.105 & 4.033 & 5.100 & 4.566 \\
\hline Ortalama & 5.634 & 5.403 & 5.519 & $4.299 \mathrm{~b}$ & $4.791 \mathrm{a}$ & 4.545 \\
\hline
\end{tabular}

** $\mathrm{P}<0.01$ düzeyinde önemli, * $\mathrm{P}<0.05$ düzeyinde önemli 
Sapa kalkma başlangıcı yaprak alan indeksi yönünden ikinci yılda Ankara Yazlığı-48 ve Polatlı Yazlığı-24 genotipleri yüksek yaprak alan indeksine sahip genotipler olmuş, Seri-82 çeşidi 4.255 değeri ile en düşük yaprak alan indeksine sahip çeşit olmuştur (Çizelge 4). İki yılın ortalaması olarak, Ankara Yazlığı-48 genotipi 6.375 değeri ile en yüksek, Seri-82 çeşidi ise 4.753 değeri ile en düşük yaprak alan indeksine sahip olmuştur. Bu araştırmadan elde edilen yaprak alan indeksleri, Koç ve Barutçular (2000) tarafından belirlenmiş olan, 4.81-6.69 arasında değişen yaprak alan indeksi değerleri ile uyum içerisindedir. Bu konuda farklı sonuçlar elde edilmiş olup, Giunta ve ark. (1995) tarafından 6.90 olarak bildirilen yaprak alan indeksi değeri bu araştırma bulgularından daha yüksek iken, Öztürk ve Akten (1999) tarafından tespit edilen 1.77- 4.73 arasındaki değerler ise daha düşüktür. Başka bir çalışmada ise, sapa kalkma başlangıcındaki yaprak alan indeksi değerlerinin 1.29-1.30 arasında değiştiği bildirilmiştir (Moraques ve ark., 2006). Gent (1995), yaprak alan indeksinde meydana gelen farklılıkların, kısmen özgül yaprak alanında meydana gelen farklııktan kaynaklandığını ortaya koymuştur. Benzer nitelikteki diğer araştırmalarda da, gerek kardeşlenme kapasitesi, gerekse yaprak sayısı ve büyüklüğündeki farklıııların bir fonksiyonu olarak, buğday genotipleri arasında yaprak alan indeksi yönünden önemli varyasyonlar olduğuna dikkat çekilmiştir (Austin ve ark., 1980; Cutfort, ve ark., 1988; Moraques ve ark., 2006).

Çiçeklenme dönemindeki yaprak alan indeksi yönünden birinci yılda Yerli Buğday-50 genotipi en yüksek yaprak alan indeksine sahip olurken, Göksun Buğdayı-51 genotipi en düşük yaprak alan indeksine sahip olmuştur. İkinci yılda, Polatlı Yazlığı-4 genotipi en yüksek, Elbistan Yazlığı33 genotipi en düşük yaprak alan indeksine sahip olmuştur. Íki yıllık ortalamalara göre, en yüksek değer 4.933 değeri ile Seri-82 çeşidinden elde edilirken, en düşük değer 4.189 ile Kırmızı Buğday21 genotipinden elde edilmiştir (Çizelge 4). Bu araştırmada elde edilen yaprak alan indeksi değerleri, Austin ve ark. (1980) ve Koç ve Barutçular (2000) tarafından bulunan değerler ile uyum içerisindedir. Austin ve ark., (1980), yaprak alan indeksi değerlerinin 2.67-8.84 arasında değiştiğini, tanede kuru madde birikiminin büyük oranda çiçeklenme sonrası fotosenteze bağlı olduğunu ve çiçeklenmedeki yaprak alan indeksi yüksek genotiplerin seçilmesiyle, çiçeklenme sonrası fotosentezde ilave artışların sağlanabileceğini belirtmişlerdir. Çiçeklenme döneminde, ikinci ürün yılındaki iklim koşullarının birinci ürün yılına göre daha elverişli olması, ikinci ürün yılında daha yüksek yaprak alan indeksi değerlerinin elde edilmesine neden olmuştur.

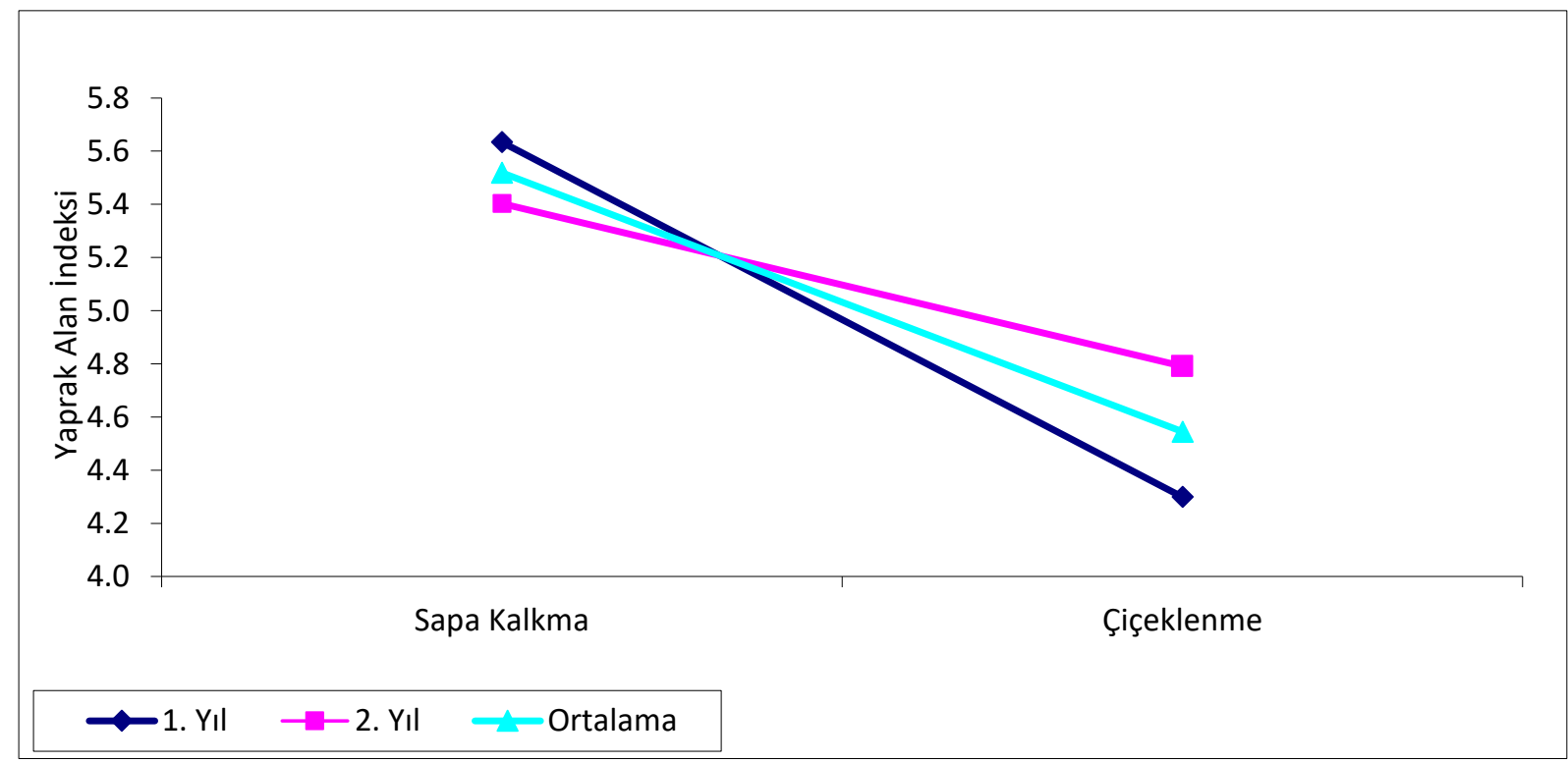

Şekil 2. Sapa kalkma başlangıcından çiçeklenme dönemine kadar yaprak alan indeksinde meydana gelen değişimler

Her iki yılda ve yılların ortalaması olarak sapa kalkma başlangıcı ile çiçeklenme dönemi arasındaki sürede, yaprak alan indeksinde azalış söz konusu olmuştur. Sapa kalkmadan çiçeklenmeye kadar olan dönem içerisinde yaprak alan indeksi ilk yılda \% 23.70, ikinci yılda \% 11.33 ve ortalama olarak \% 17.65 civarında azalma göstermiştir. Buğday bitkisinde yaprak alan indeksindeki artış, çıkıştan itibaren giderek artan bir hızla devam etmekte ve çiçeklenmeden 2-3 hafta önce en 
yüksek değerine ulaşmaktadır. Bundan sonraki dönemlerde ise yaşlanmaya bağlı yaprak kayıpları nedeniyle giderek azalmaktadır (Koç ve Barutçular, 2000). Bizim bulgularımızda da sapa kalkma dönemindeki yaprak alan indeksi en yüksek değere sahip olmuş, çiçeklenme döneminde ise yaprak alanı indeksi değerinde azalma söz konusu olmuştur (Şekil 2). Hafid ve ark. (1998) ve Moraques ve ark. (2006) bizim bulgularımıza benzer şekilde sapa kalkmada daha yüksek yaprak alan indeksi, çiçeklenmede ise daha düşük yaprak alan indeksi değeri bulmuşlardır.

\section{Özgül yaprak alanı}

Dört yapraklı dönemdeki özgül yaprak alanı bakımından genotipler arasındaki farklar ilk yılda, ikinci yılda ve yılların birlikte analizi ( $P \leq 0.01$ ) sonucunda önemli bulunurken yıllar arasındaki fark ve yıl $X$ genotip interaksiyonu istatistiki olarak önemsiz bulunmuştur. Birinci yılda dört yapraklı dönemde özgül yaprak alanı bakımından, Adana-99 çeşidi $360.34 \mathrm{~cm}^{2} / \mathrm{g}$ ile ilk sırada yer almış, Kırmızı
Buğday-21 genotipi $113.33 \mathrm{~cm}^{2} / \mathrm{g}$ ile en düşük özgül yaprak alanına sahip genotip olmuştur (Çizelge 5). İkinci yılda, Golia ve Ofis Yazlığı-35 genotipleri yüksek özgül yaprak alanına sahip olmuşlar, Kırmızı Buğday-21 $195.60 \mathrm{~cm}^{2} / \mathrm{g}$ ile en düşük değere sahip genotip olmuştur. Yerel ekmeklik buğday genotiplerinin iki yıllık ortalama verileri incelendiğinde, en yüksek değer Golia çeşidinden $312.94 \mathrm{~cm}^{2} / \mathrm{g}$ ile elde edilmiştir. Golia çeşidi dışındaki 6 genotip de bu standart çeşitle aynı grupta yer almıştır. En düşük özgül yaprak alanı değeri ise $154.47 \mathrm{~cm}^{2} / g$ ile Kırmızı Buğday-21 genotipinden elde edilmiştir. Rebetzke ve ark. (2004), özgül yaprak alanı değerlerinin 267-317 $\mathrm{cm}^{2} / \mathrm{g}$ arasında değiştiğini belirtirken, Rawson ve ark. (1987), 324-357 cm²/g arasında değiştiğini belirtmişlerdir. Özgül yaprak alanında meydana gelen değişimlerin; yaprağın bitki üzerinde bulunduğu yere, yaprağın yaşına, bitki sıklığına, ışık miktarına ve genotipe bağlı olarak değiştiği ifade edilmiştir (Rawson ve ark., 1987).

Çizelge 5. Yerel ve standart ekmeklik buğday genotiplerinde dört yapraklı dönemdeki ve sapa kalkma başlangıcındaki özgül yaprak alanına ilişkin ortalama değerler

\begin{tabular}{|c|c|c|c|c|c|c|}
\hline \multirow[t]{2}{*}{ Genotipler } & \multicolumn{3}{|c|}{$\begin{array}{c}\text { Dört yapraklı dönemdeki özgül yaprak } \\
\text { alanı }\left(\mathrm{cm}^{2} / \mathrm{g}\right)\end{array}$} & \multicolumn{3}{|c|}{$\begin{array}{c}\text { Sapa kalkma başlangıcındaki özgül yaprak } \\
\text { alanı }\left(\mathrm{cm}^{2} / \mathrm{g}\right)\end{array}$} \\
\hline & 1.YıI** & 2. YוI** & Ort. ${ }^{* *}$ & $1 . Y_{\text {II }} * *$ & 2. YוI** & Ort. ${ }^{*}$ \\
\hline Polatlı Yazlığı-4 & $231.17 \mathrm{bcd}$ & $279.95 a b$ & $255.56 \mathrm{abc}$ & $170.85 \mathrm{bc}$ & $332.37 \mathrm{ab}$ & $251.61 \mathrm{abcd}$ \\
\hline Alabuğday-5 & $217.72 \mathrm{bcd}$ & $218.98 \mathrm{~cd}$ & $218.35 \mathrm{c}$ & $217.49 \mathrm{bc}$ & $293.90 \mathrm{abcd}$ & $255.70 \mathrm{abcd}$ \\
\hline Alabuğday-11 & $232.29 \mathrm{bcd}$ & $251.90 \mathrm{abcd}$ & $242.10 \mathrm{bc}$ & $173.13 \mathrm{bc}$ & 259.11 cde & $216.12 d$ \\
\hline Ak Buğday-13 & $224.50 \mathrm{bcd}$ & $207.88 \mathrm{~cd}$ & $216.19 \mathrm{c}$ & $171.63 \mathrm{bc}$ & 267.69 bcde & $219.66 \mathrm{~cd}$ \\
\hline Nurhak Buğdayı-19 & $220.14 \mathrm{bcd}$ & $244.73 \mathrm{abcd}$ & $232.43 c$ & 182.96 bc & $253.31 \mathrm{de}$ & $218.14 \mathrm{~cd}$ \\
\hline Kırmızı Buğday-21 & $113.33 \mathrm{~d}$ & $195.60 \mathrm{~d}$ & $154.47 d$ & $211.82 \mathrm{bc}$ & 260.12 cde & $235.97 \mathrm{bcd}$ \\
\hline Polatlı Yazlığı-24 & $200.96 \mathrm{~cd}$ & $244.98 \mathrm{abcd}$ & $222.97 \mathrm{c}$ & $144.53 \mathrm{c}$ & $330.37 a b$ & $237.45 \mathrm{bcd}$ \\
\hline Beyaz Buğday-31 & $209.91 \mathrm{bcd}$ & $235.83 \mathrm{abcd}$ & $222.87 \mathrm{c}$ & $188.53 \mathrm{bc}$ & $359.56 \mathrm{a}$ & $274.05 a b$ \\
\hline Elbistan Yazlığı-33 & $204.88 \mathrm{~cd}$ & $265.30 a b c$ & $235.09 c$ & $221.65 b$ & $306.15 \mathrm{abcd}$ & $263.90 \mathrm{abcd}$ \\
\hline Ofis Yazlığı-35 & $237.05 \mathrm{bc}$ & $288.23 \mathrm{a}$ & $262.64 \mathrm{abc}$ & $209.33 \mathrm{bc}$ & $326.74 \mathrm{abc}$ & $268.03 \mathrm{abc}$ \\
\hline Ankara Yazlığı-48 & $233.08 \mathrm{bcd}$ & $254.53 a b c$ & $243.80 \mathrm{bc}$ & $184.26 \mathrm{bc}$ & $314.98 \mathrm{abcd}$ & $249.62 \mathrm{abcd}$ \\
\hline Ziron Yazlığı-49 & $298.20 \mathrm{abc}$ & $234.70 \mathrm{abcd}$ & $266.45 \mathrm{abc}$ & $177.11 \mathrm{bc}$ & $335.97 a b$ & $256.54 \mathrm{abcd}$ \\
\hline Yerli Buğday-50 & $255.86 \mathrm{abc}$ & $256.95 a b c$ & $256.41 \mathrm{abc}$ & $184.97 \mathrm{bc}$ & $329.51 \mathrm{ab}$ & $257.24 \mathrm{abcd}$ \\
\hline Göksun Buğdayı-51 & $244.02 a b c$ & $228.40 \mathrm{bcd}$ & $236.21 \mathrm{c}$ & $186.36 \mathrm{bc}$ & $299.59 \mathrm{abcd}$ & $242.97 \mathrm{bcd}$ \\
\hline Adana-99 & $360.34 \mathrm{a}$ & $255.33 \mathrm{abc}$ & $307.83 a b$ & $287.53 \mathrm{a}$ & $225.78 \mathrm{e}$ & $256.65 \mathrm{abcd}$ \\
\hline Seri-82 & $272.89 a b c$ & $284.23 a b$ & $278.56 \mathrm{abc}$ & $318.01 \mathrm{a}$ & 275.14 bcde & 296.57 a \\
\hline Golia & $332.90 \mathrm{ab}$ & $292.98 \mathrm{a}$ & $312.94 \mathrm{a}$ & $294.80 \mathrm{a}$ & 273.84 bcde & $284.32 \mathrm{ab}$ \\
\hline Ortalama & 240.54 & 249.44 & 244.99 & $207.35 \mathrm{~b}$ & $296.71 \mathrm{a}$ & 252.03 \\
\hline
\end{tabular}

** $\mathrm{P}<0.01$ düzeyinde önemli, * $\mathrm{P}<0.05$ düzeyinde önemli

Sapa kalkma başlangıcındaki özgül yaprak alanı bakımından genotiplerin aralarındaki farklar ilk yılda, ikinci yılda ( $P \leq 0.01)$ ve iki yıllık ortalamalarda önemli ( $P \leq \quad 0.05$ ) olmuştur. Çalışmada ilk yıl, özgül yaprak alanı değerlerinin genotiplere göre 144.53-318.01 cm²/g arasında değiştiği belirlenmiştir. İki yıllık ortalama veriler incelendiğinde, en yüksek özgül yaprak alanı değeri
Seri-82 (296.57 cm²/g) çeşidinden, en düşük değer ise $\left(216.12 \mathrm{~cm}^{2} / \mathrm{g}\right)$ Alabuğday-11 genotipinden elde edilmiştir. Sapa kalkma başlangıcındaki özgül yaprak alanı yönünden yıllar arasındaki fark önemli olmuştur ( $P \leq$ 0.01). Denemenin ilk yılında elde edilen değerler genel olarak ikinci yılda elde edilen değerlerden oldukça düşük olmuştur. İkinci yılda ölçülen yaprak alanı değerinin (Çizelge 5), birinci 
yılda belirlenen yaprak alanı değerinden daha yüksek olması nedeniyle ikinci yıldaki özgül yaprak alanı daha yüksek bulunmuştur (Lopez-Castaneda ve ark., 1995). Adana-99, Seri-82 ve Golia standart çeşitlerinde özgül yaprak alanı birinci yıl yüksek, ikinci yıl düşük olmuştur. Ayrıca, Polatlı Yazlığı-4, Polatı Yazlığı-24 ve Elbistan Yazlığı-33 genotipleri de yıllara göre kararlı bir durum göstermemiştir. Bu durum, genotiplerin iklim faktörlerine farklı tepki vermelerinden, özellikle de sıcaklıktan etkilenmelerinden kaynaklanmış olabilir. Özgül yaprak alanının, ışık yoğunluğu (Friend, 1966), ışık kalitesi (Casal ve ark., 1987) ve sıcaklık (Hotsonyame ve Hunt, 1998) tarafından etkilendiği belirlenmiştir.

Çiçeklenme dönemindeki özgül yaprak alanı, ilk yılda ve yılların birlikte analizi sonucunda çiçeklenme dönemindeki özgül yaprak alanı bakımından genotipler arasındaki fark \%1 seviyesinde önemli olurken, ikinci yıl istatistikî olarak önemsiz olmuştur. Birinci yılda en yüksek özgül yaprak alanı değeri $205.28 \mathrm{~cm}^{2} / \mathrm{g}$ ile Polatlı Yazlığı-24 genotipinden, en düşük özgül yaprak alanı değeri ise Adana-99, Seri-82 ve Golia standart çeşitlerinden elde edilmiştir. İki yıllık ortalama sonuçlara göre, Polatlı Yazlığı-24, Ziron Yazlığı-49 ve Ankara Yazlığı-48 genotiplerinde yüksek, Adana-99 çeşidinde ise en düşük özgül yaprak alanı elde edilmiştir (Çizelge 6). Her iki yılda da standart çeşitler yerel genotiplerden oldukça düşük özgül yaprak alanına sahip olmuştur. Standart çeşitlerin daha erken çiçeklenme dönemine girmesi, yerel genotiplerin ise daha geç ve Mayıs ayı içerisinde çiçeklenmesi ve yaprak alanlarında ki artışın yansıması olarak, özgül yaprak alanı değerlerinin daha yüksek bulunmasına neden olmuştur. Genotiplerin çiçeklenme dönemindeki özgül yaprak alanı değerlerinin 180.1 ile $185.4 \mathrm{~cm}^{2} / \mathrm{g}$ arasında değişim gösterdiği saptanmıştır (Dreccer ve ark., 2009). Çiçeklenme döneminde, ikinci yılda tüm genotiplerin özgül yaprak alanlarında ilk yıla göre artışlar olmuş ve yıllar arasındaki fark önemli olmuştur ( $P \leq 0.01)$. Özellikle ikinci yıldaki Nisan ve Mayıs aylarındaki yağışın, birinci yıldan ve uzun yıllar ortalamasından daha yüksek olması özgül yaprak alanında artışlara neden olmuştur. Birinci yılda meydana gelen kuraklık stresi (Nisan ve Mayıs ayları) sonucunda özgül yaprak alanında azalma meydana gelmiştir (Liu ve Stützel, 2004). Ayrıca, ikinci yılda belirlenen yaprak alanı değerinin, birinci yıldan daha yüksek olması sonucu özgül yaprak alanı daha yüksek bulunmuştur (Lopez-Castaneda ve ark., 1995).

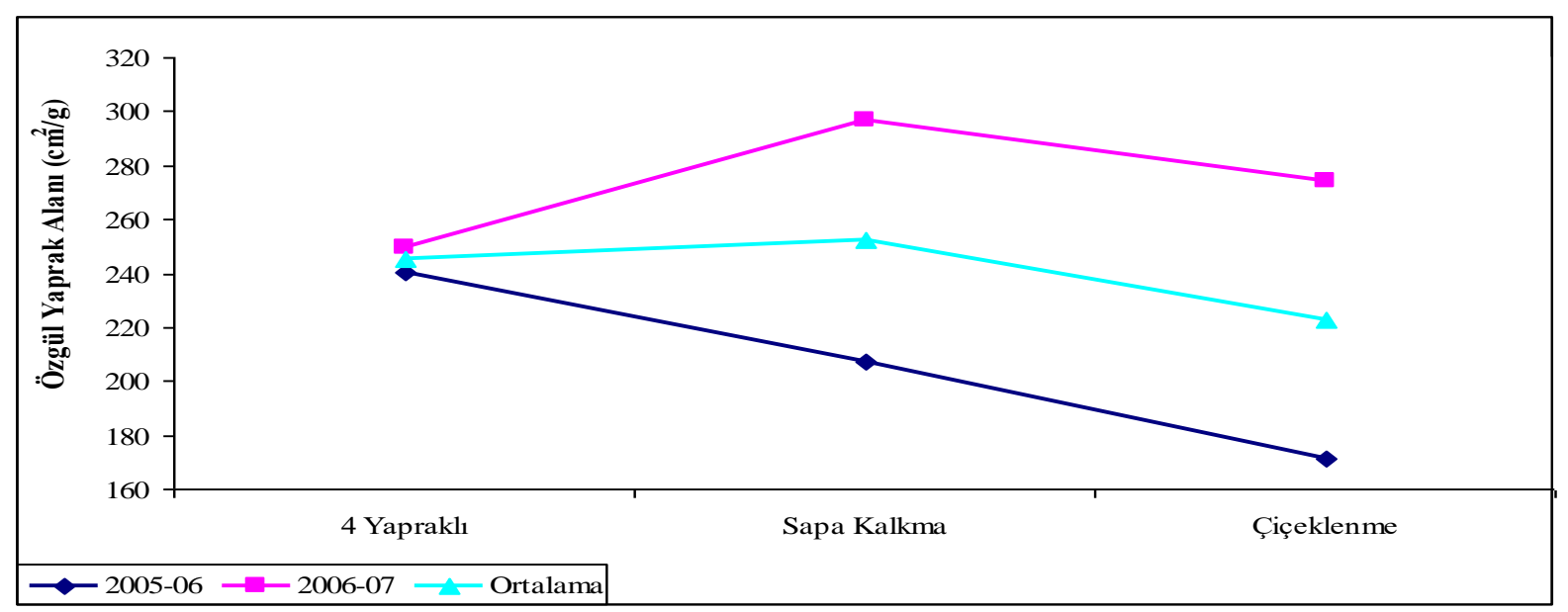

Şekil 3. Farklı dönemlerde özgül yaprak alanında meydana gelen değişimler

Dört yapraklı dönemde özgül yaprak alanı her iki yılda da birbirine yakın değerler göstermiş ancak, sapa kalkma döneminde özgül yaprak alanı değeri ilk yıl düşerken, ikinci yıl artmıştır (Şekil 3). Çiçeklenme döneminde ise her iki yılda da azalma meydana gelmiştir. ilk yılda sapa kalkmanın gerçekleştiği dönemde, ikinci yıldan ve uzun yıllar ortalamasından oldukça düşük meydana gelen yağış ve yine bu dönemde meydana gelen yüksek sıcaklıklar özgül yaprak alanının oldukça düşük olmasına neden olmuştur (Marcelis ve ark., 1998;
Liu ve Stützel, 2004). Buğdayda maksimum özgül yaprak alanı için optimum sıcaklığın $20^{\circ} \mathrm{C}$ olduğu, 5 . yaprağa kadar özgül yaprak alanının arttığı, 5 . yapraktan sonra büyümenin ilerlemesiyle birlikte oluşan yapraklarda özgül yaprak alanının düştüğü (Hotsonyame ve Hunt, 1998), özgül yaprak alanının, özellikle erken gelişme dönemlerindeki kuru madde birikimi ve yaprak alanı artışı üzerinde önemli bir etkiye sahip olduğu belirtilmiştir (Rawson ve ark., 1987). 
Çizelge 6. Yerel ve standart ekmeklik buğday genotiplerinde çiçeklenme dönemindeki özgül yaprak alanı ve tane dolum periyoduna ilişkin ortalama değerler

\begin{tabular}{|c|c|c|c|c|c|c|}
\hline \multirow[t]{2}{*}{ Genotipler } & \multicolumn{3}{|c|}{$\begin{array}{c}\text { Çiçeklenme dönemindeki özgül yaprak } \\
\text { alanı }\left(\mathrm{cm}^{2} / \mathrm{g}\right)\end{array}$} & \multicolumn{3}{|c|}{ Tane dolum periyodu (gün) } \\
\hline & $1 . Y I^{* *}$ & 2. YII & Ort. ${ }^{* *}$ & $1 .\left.Y_{I}\right|^{* *}$ & 2. YıI** & Ort. ${ }^{* *}$ \\
\hline Polatlı Yazlığı-4 & $184.90 \mathrm{abc}$ & 304.20 & $244.55 a b$ & $31.3 \mathrm{bcd}$ & $30.3 \mathrm{abcd}$ & 30.8 bcde \\
\hline Alabuğday-5 & $178.47 \mathrm{abc}$ & 256.60 & 217.54 abcde & 30.3 cde & $31.8 \mathrm{ab}$ & $31.0 \mathrm{bcd}$ \\
\hline Alabuğday-11 & $171.84 \mathrm{bc}$ & 221.71 & 196.78 bcde & $29.5 \mathrm{e}$ & $30.3 \mathrm{abcd}$ & 29.9 def \\
\hline Ak Buğday-13 & $168.29 \mathrm{bc}$ & 255.24 & 211.77 abcde & 30.0 de & $28.8 \mathrm{bcd}$ & 29.4 def \\
\hline Nurhak Buğdayı-19 & 167.19 c & 290.95 & $229.07 \mathrm{abcd}$ & $29.5 \mathrm{e}$ & $28.8 \mathrm{bcd}$ & 29.1 ef \\
\hline Kırmızı Buğday-21 & $167.92 \mathrm{bc}$ & 306.96 & $237.44 a b c$ & 31.0 bcde & $32.5 \mathrm{a}$ & $31.8 \mathrm{bc}$ \\
\hline Polatlı Yazlığı-24 & 205.28 a & 307.96 & 256.62 a & 30.0 de & $27.5 \mathrm{~d}$ & $28.8 f$ \\
\hline Beyaz Buğday-31 & $161.24 \mathrm{~cd}$ & 325.80 & $243.52 a b$ & $32.3 \mathrm{~b}$ & $32.5 \mathrm{a}$ & $32.4 \mathrm{~b}$ \\
\hline Elbistan Yazlığı-33 & $172.47 a b c$ & 256.17 & 214.32 abcde & $29.8 \mathrm{de}$ & $27.5 \mathrm{~d}$ & $28.6 \mathrm{f}$ \\
\hline Ofis Yazlığı-35 & $189.90 \mathrm{abc}$ & 299.14 & $244.52 \mathrm{ab}$ & 30.5 cde & $30.3 \mathrm{abcd}$ & 30.4 cdef \\
\hline Ankara Yazlığı-48 & $201.27 a b$ & 293.12 & $247.20 \mathrm{a}$ & 31.8 bc & $29.0 \mathrm{bcd}$ & 30.4 cdef \\
\hline Ziron Yazlığı-49 & $187.74 a b c$ & 316.67 & $252.20 \mathrm{a}$ & 30.5 cde & $27.5 \mathrm{~d}$ & 29.0 ef \\
\hline Yerli Buğday-50 & $161.73 \mathrm{~cd}$ & 275.51 & $218.62 \mathrm{abcd}$ & 30.8 bcde & $28.0 \mathrm{~cd}$ & 29.4 def \\
\hline Göksun Buğdayı-51 & $185.77 a b c$ & 258.27 & $222.02 \mathrm{abcd}$ & 30.8 bcde & $32.8 \mathrm{a}$ & $31.8 \mathrm{bc}$ \\
\hline Adana-99 & $134.00 \mathrm{~d}$ & 209.21 & $171.60 \mathrm{e}$ & $41.0 \mathrm{a}$ & $31.8 \mathrm{ab}$ & $36.4 \mathrm{a}$ \\
\hline Seri-82 & $135.75 \mathrm{~d}$ & 246.06 & $190.91 \mathrm{cde}$ & $40.3 \mathrm{a}$ & $31.0 \mathrm{abc}$ & $35.6 \mathrm{a}$ \\
\hline Golia & $134.20 \mathrm{~d}$ & 242.48 & $188.34 \mathrm{de}$ & $41.0 \mathrm{a}$ & $31.0 \mathrm{abc}$ & $36.0 \mathrm{a}$ \\
\hline Ortalama & $171.06 \mathrm{~b}$ & $274.47 \mathrm{a}$ & 222.76 & $32.4 \mathrm{a}$ & $30.1 \mathrm{~b}$ & 31.2 \\
\hline
\end{tabular}

** $\mathrm{P}<0.01$ düzeyinde önemli, * $\mathrm{P}<0.05$ düzeyinde önemli

\section{Tane dolum periyodu}

Tane dolum periyodu değerlerine bakıldığında, genotipler arasındaki farklar birinci yıl, ikinci yıl ve yılların birlikte analizi durumunda istatistiksel olarak önemli bulunmuştur ( $P \leq 0.01)$. ilk yıl, en uzun tane dolum periyotları Adana-99, Seri-82 ve Golia standart çeşitlerinde söz konusu olmuştur. Alabuğday-11 ve Nurhak Buğdayı-19 genotipleri 29.5 gün ile en kısa tane dolum periyoduna sahip genotipler olmuşlardır. İkinci yıl, tane dolum periyotları 27.5-32.8 gün arasında değişmiştir. İki yılın ortalaması olarak standart çeşitler uzun tane dolum periyoduna sahip çeşitler olarak belirlenmiştir. Tane dolum periyodu standart çeşitlerde 35.6-36.4 gün, yerel genotiplerde ise 28.6-32.4 gün arasında değişmiştir. Araştırmada kullanılan yerel buğday genotiplerinin tane dolum periyotları standart çeşitlerden oldukça kısa olmuştur (Çizelge 6). Aynı iklim ve yetiştirme koşullarında tane dolum periyodu yönünden ortaya çıkan farklar genetik yapıdan kaynaklanmaktadır. Borojevic ve Williams (1982), Gebeyehou ve ark. (1982a), Gebeyehou ve ark. (1982b), Sharma (1994) gibi araştırıcılar, uzun tane dolum periyoduna sahip genotiplerin yüksek verimli olduklarını belirterek, tane dolum periyodunun uzamasının geç döllenen çiçeklerin tane bağlama şansını artırmak ve başakçık kayıplarını azaltmak suretiyle, başaktaki tane sayısını ve dolayısıyla verimi artırdığını bildirmişlerdir. Tane dolum periyodu yönünden yıllar ve yıl $X$ genotip interaksiyonu arasındaki fark önemli bulunmuştur ( $P \leq 0.01$ ). ilk ürün yılında tane dolum periyodu 32.4 gün iken, ikinci ürün yılında 30.1 gün olmuştur (Çizelge 6). Çiçeklenme sonrası gelişme döneminde, birinci ürün yılındaki iklim koşullarının ikinci ürün yılına göre daha elverişli olması, birinci ürün yılında daha uzun tane dolum periyodu değerlerinin elde edilmesine neden olmuştur. Tane dolum periyodunun çiçeklenme sonrası dönemdeki yağış miktarı ve sıcaklık dereceleri ile yakın ilişkili olduğu, bu dönemdeki nem yetersizliği ve yüksek sıcaklıkların tane dolum periyodunu önemli derecede sınırladığı tespit edilmiştir (Bruckner ve Frohberg, 1987; Öztürk ve Akkaya, 1996).

\section{Yaprak alan süresi}

Yaprak alanı süresi bakımından genotipler arasındaki farklılıklar ikinci yıl önemsiz olurken, birinci yıl, iki yıllık ortalamalar, yıllar arasındaki fark ve yıl $X$ genotip interaksiyonu istatistikî olarak önemli ( $P \leq 0.01)$ olmuştur.

Birinci yıl, Adana-99 ve Seri-82 çeşitleri en uzun yaprak alan süresine sahip olmuştur. Alabuğday-11 ve Kırmızı Buğday-21 genotipleri ise 17 genotip içerisinde en kısa yaprak alan süresine sahip genotipler olmuşlardır. İki yıllık ortalamalara göre, en uzun yaprak alanı süreleri Adana-99 ve Seri-82 standart çeşitlerinden elde edilirken, en 
kısa yaprak alanı süresi ise 112.1 gün ile Elbistan Yazlığı-33 genotipinden elde edilmiştir (Çizelge 7). Buğday genotiplerinin, farklı tane dolum periyodu ve yaprak alan indeksi değerlerine sahip olmaları, bu özelliklerin bir unsuru olan yaprak alan süresinin de genotiplere göre farklı olmasına neden olmuştur. Yaprak alanı süresi yönünden genotipler arasında önemli farkların bulunduğu (Olgun ve ark., 1999; Tiryakioğlu, 2004), yaprak alanı süresi büyük olan çeşitlerde tane veriminin de yüksek olduğu belirlenmiştir (Tiryakioğlu, 2004). Yaprak alanı süresi bakımından yıllar arasındaki fark önemli bulunmuştur ( $P \leq$ 0.01). Deneme yıllarının ortalaması olarak yaprak alanı süresi ilk yıl 112.3 gün iken, ikinci yıl 141.2 gün olmuştur. Birinci ürün yılında, çiçeklenme sonrası yağış ve sıcaklık yönünden daha elverişli iklim koşullarının etkili olması nedeniyle tane dolum periyodu daha uzun olmasına rağmen, ikinci yıldaki yaprak alan indeksinin çok yüksek olması, bu yılda daha uzun yaprak alanı süresi sağlamıştır. İkinci yılda meydana gelen yüksek yağışlar, yaprak yaşlanmasını geciktirerek yaprak alan süresinin uzamasına neden olmuştur. Konuyla ilgili yapılan bir araştırmada, çiçeklenme sonrası dönemde yeterli yağışın ve toprak neminin olduğu yıllarda yaprak yaşlanmasının daha yavaş olduğu ve daha yüksek yaprak alanı süresinin elde edildiği belirtilmiştir (Gent ve Kiyomoto, 1992).

Çizelge 7. Yerel ve standart ekmeklik buğday genotiplerinde yaprak alan süresine ilişkin ortalama değerler

\begin{tabular}{|c|c|c|c|c|c|c|}
\hline \multirow{2}{*}{ Genotipler } & \multicolumn{3}{|c|}{ Yaprak alan süresi (gün) } & \multicolumn{3}{|c|}{ Olgunlaşma dönemindeki biyomas $(\mathrm{kg} / \mathrm{da})$} \\
\hline & 1.Yı** & 2. YII & Ort. ** & 1.YıI** & 2. $Y_{I I} * *$ & Ort.** \\
\hline Polatlı Yazlığı-4 & $125.4 \mathrm{bc}$ & 149.1 & $137.3 \mathrm{ab}$ & $1467 \mathrm{abc}$ & 1449 ef & 1458 def \\
\hline Alabuğday-5 & 108.2 cde & 145.3 & $126.7 \mathrm{abc}$ & $1658 a b$ & 1558 bcdef & 1608 bcde \\
\hline Alabuğday-11 & 87.7 e & 161.8 & $124.8 \mathrm{abc}$ & $1585 a b$ & 1446 ef & 1515 cdef \\
\hline Ak Buğday-13 & 109.6 cde & 126.6 & 118.1 bc & 1676 a & 1658 bcde & $1667 \mathrm{abc}$ \\
\hline Nurhak Buğdayı-19 & $100.1 \mathrm{de}$ & 129.9 & $115.0 \mathrm{bc}$ & $1659 a b$ & 1528 cdef & 1594 bcde \\
\hline Kırmızı Buğday-21 & $87.3 \mathrm{e}$ & 150.9 & 119.1 bc & $1439 a b c$ & $1772 \mathrm{abcd}$ & 1606 bcde \\
\hline Polatlı Yazlığı-24 & $98.2 \mathrm{de}$ & 128.8 & $113.5 \mathrm{bc}$ & $1447 \mathrm{abc}$ & $1340 \mathrm{f}$ & $1393 f$ \\
\hline Beyaz Buğday-31 & 103.5 cde & 144.9 & $124.2 \mathrm{abc}$ & $1492 a b$ & 1641 bcdef & 1567 bcdef \\
\hline Elbistan Yazlığı-33 & 101.4 cde & 122.8 & $112.1 \mathrm{c}$ & $1457 \mathrm{abc}$ & 1490 def & 1473 cdef \\
\hline Ofis Yazlığı-35 & $113.0 \mathrm{~cd}$ & 149.7 & $131.3 \mathrm{abc}$ & $1540 a b$ & 1623 bcdef & 1582 bcdef \\
\hline Ankara Yazlığı-48 & 108.8 cde & 142.6 & $125.7 \mathrm{abc}$ & 1412 bc & 1469 ef & 1440 ef \\
\hline Ziron Yazlığı-49 & 106.8 cde & 124.5 & $115.7 \mathrm{bc}$ & $1517 a b$ & 1370 ef & 1443 ef \\
\hline Yerli Buğday-50 & $117.3 \mathrm{bcd}$ & 149.6 & $133.4 \mathrm{abc}$ & 1411 bc & 1540 bcdef & 1475 cdef \\
\hline Göksun Buğdayı-51 & $96.1 \mathrm{de}$ & 163.7 & $129.9 \mathrm{abc}$ & $1626 a b$ & 1664 bcde & $1645 \mathrm{bcd}$ \\
\hline Adana-99 & $153.3 \mathrm{a}$ & 142.3 & $147.8 \mathrm{a}$ & $1640 a b$ & 2011 a & 1825 a \\
\hline Seri-82 & $155.2 \mathrm{a}$ & 131.8 & $143.5 \mathrm{a}$ & $1608 a b$ & $1838 a b$ & $1723 a b$ \\
\hline Golia & $136.9 \mathrm{ab}$ & 136.9 & $136.9 \mathrm{ab}$ & $1237 c$ & $1794 \mathrm{abc}$ & $1516 \mathrm{cdef}$ \\
\hline Ortalama & $112.3 \mathrm{~b}$ & $141.2 \mathrm{a}$ & 126.8 & $1522 \mathrm{~b}$ & 1599 a & 1560 \\
\hline
\end{tabular}

** $\mathrm{P}<0.01$ düzeyinde önemli

\section{Olgunlaşma dönemindeki biyomas}

Olgunlaşma dönemindeki biyomas

bakımından genotipler arasındaki farklar, her iki yıl, iki yılın birlikte analizi, yıllar arasındaki fark ve yıl $\mathrm{X}$ genotip interaksiyonuna göre istatistikî olarak önemli bulunmuştur ( $P \leq 0.01)$. Birinci yıl tane verimi 1237 ile $1676 \mathrm{~kg} / \mathrm{da}$ arasında, ikinci yıl 1340 ile 2011 kg/da arasında gerçekleşmiştir. İki yıllık ortalama sonuçlara göre, Adana-99 çeşidi 1825 $\mathrm{kg} / \mathrm{da}$ ile en yüksek biyomasa sahip olmuştur. Polatlı Yazlığı-24 genotipi 1393 kg/da ile en düşük biyomas verimi sağlamıştır (Çizelge 7). Bu araştırmadan elde edilen biyomas verimleri, Bahar ve ark. (2008) tarafından belirlenen, 1276-1629 $\mathrm{kg} / \mathrm{da}$ ve Dreccer ve ark. (2009) tarafından belirlenen $1136-1887 \mathrm{~kg} / \mathrm{da}$ arasındaki biyomas verimleriyle uyum içerisindedir. Monneveux ve ark.
(2006) tarafından $1801 \mathrm{~kg} / \mathrm{da}$ olarak bildirilen biyomas verimi bu araştırma bulgularından daha yüksek iken, Condon ve ark. (1993) tarafından tespit edilen $885-1092 \mathrm{~kg} / \mathrm{da}$ ve Kuşcu (2006) tarafından belirlenen $1029-1203 \mathrm{~kg} / \mathrm{da}$ arasındaki değerler ise daha düşüktür. Başka bir çalışmada ise, olgunlaşma dönemi biyomas değerlerinin 1210$1500 \mathrm{~kg} /$ da arasında değiştiği bildirilmiştir (De Vita ve ark., 2007). Araştırma, yağışa dayalı koşullarda yürütüldüğü için buğday yetiştirme sezonu boyunca yağış miktarı biyomas verimi üzerinde doğal olarak etkili olmuştur. Araştırmanın ikinci yılındaki toplam yağış yetersiz olmasına rağmen, Nisan ve Mayıs ayında düşen yeterli yağış biyomas veriminde önemli artış sağlamış, birinci yıl aynı aylardaki yetersiz yağış nedeniyle biyomas verimi daha düşük olmuştur. Kırmızı Buğday-21, Polatlı Yazlığı-24, Ziron Yazlığı-49, 
Yerli Buğday-50, Adana-99 ve Golia genotipleri yıllara göre değişen iklim faktörlerine karşı farklı tepkiler göstermişlerdir.

\section{Tane verimi}

Tane verimi yönünden yılların ayrı ayrı, birlikte analizi sonucunda, yıllar arasındaki farklar ve yıl $X$ genotip interaksiyonunun $\% 1$ seviyesinde önemli olduğu belirlenmiştir. İlk yıl, en yüksek tane verimi, $616.8 \mathrm{~kg} / \mathrm{da}$ ile Seri-82 standart çeşidinden en düşük tane verimi Ziron Yazlığı-49 genotipinden $302.3 \mathrm{~kg} / \mathrm{da}$ ile elde edilmiştir. İkinci yıl, standart çeşitler (Adana-99, Seri-82 ve Golia) yerel çeşitlerden önemli derecede yüksek tane verimine sahip olmuşlardır. Yerel genotipler düşük tane verimine sahip olmuşlar ve kendi aralarındaki farklar önemli olmamıştır (Çizelge 8). İki yıllık ortalamalara göre, yine standart çeşitler yüksek tane verimine sahip olmuşlar ve kendi aralarındaki farklar önemli olmazken, yerel çeşitlerle aralarındaki farklar önemli olmuştur. Tane verimi standart çeşitlerde 562.1-635.4 kg/da, yerel genotiplerde ise $267.6-354.8 \mathrm{~kg} / \mathrm{da}$ arasında değişim göstermiştir. Tane verimi yönünden elde edilen sonuçların genotiplere göre değiştiği diğer araştırıcılar tarafından da belirlenmiştir (Bilgin ve Korkut, 2005; Monneveux ve ark., 2006; Öztürk ve Gökkuş, 2008; Dreccer ve ark., 2009).

Yağışa dayalı koşullarda yürütülen bu denemede, genotiplerin ortalaması olarak tane verimi ilk yıl $396.8 \mathrm{~kg} / \mathrm{da}$, ikinci yıl $346.1 \mathrm{~kg} / \mathrm{da}$ olmuştur. Yetişme mevsimi boyunca birinci yıldaki yağış miktarı ikinci yıldan daha yüksek olmuştur. Ayrıca, ikinci yılda çiçeklenme sonrası görülen yüksek sıcaklıklar tane dolum periyodunun kısalmasına neden olmuştur. Birinci yıldaki elverişli iklim koşullarına bağlı olarak tane dolum periyodu daha uzun olmuş, sonuçta bu karakterle olumlu ilişki (Siddique ve ark., 1989b) içerisinde olan tane verimi de artmıştır. Çiçeklenmeden sonraki yüksek sıcaklıkların tane verimini azalttığı belirtilmiştir (Loss ve Siddique, 1994). Sıcaklık arttıkça solunum kayıplarının arttığı bu yüzden de büyüme için gerekli asimilatların azaldığı ve tane dolum süresinin kısaldığı belirtilmiştir (Gusta ve Chen, 1987; Wardlaw ve ark., 1989). Tane veriminin sıcaklıkla olumsuz (Ferris ve ark., 1998), yağış miktarıyla olumlu (Zhang ve ark., 1998) ilişkiler gösterdiği, $30^{\circ} \mathrm{C}$ 'nin üzerindeki sıcaklıkların tane verimini düşürdüğü (Plaut ve ark., 2003; Rana ve Nagarajan, 2004) bildirilmiştir. Tane verimi yönünden ürün yıllarına göre ortaya çıkan farkların, başak gelişmesi-fizyolojik olgunluk dönemi arasındaki sıcaklık (Spiertz ve Vos, 1985), toplam yağış miktarı ve dağılımı (Mahler ve ark., 1994) ile yakından ilişkili olduğu ifade edilmiştir. Adana-99, Seri-82 ve Golia standart çeşitleri Nisan ayı sonlarında, diğer genotipler ise Mayıs ayı içerisinde çiçeklenmişlerdir. Nisan ayındaki ortalama sıcaklık değeri ikinci yılda, ilk yıldan ve uzun yıllar ortalamasından daha düşük olmuştur. Ayrıca, Nisan ve Mayıs ayında düşen yeterli yağış standart çeşitlerde, biyomas veriminde olduğu gibi tane veriminde de önemli artış sağlarken, birinci yılda aynı aylardaki yetersiz yağış standart çeşitlerin tane veriminin daha düşük olmasına neden olmuştur. Ayrıca ikinci yılda Mayıs ayı içerisinde maksimum sıcaklıkların $30^{\circ} \mathrm{C}^{\prime}$ nin üzerinde olduğu gün sayısı 18 olarak belirlenmiştir. Tane dolum döneminin hemen başında meydana gelmiş olan bu yüksek sıcaklıklar ve nem değerleri, tanelerin büzüşmesine sebep olarak verimin düşmesine neden olmuşlardır (Tashiro ve Wardlaw, 1990). Denemenin ikinci yılında etkili olan yüksek sıcaklıklara bağlı olarak tane dolum periyodu kısalmıştır. İkinci yıldaki yüksek sıcaklıkların bu iki özellik üzerindeki olumsuz etkilerinin tane verimine de yansımış olma intimali oldukça yüksektir. İkinci yılda belirtilen bu olumsuz koşullar, geççi olan yerel genotipler üzerinde olumsuz etki yaparken, erkenci olan standart çeşitler (Adana-99, Seri-82, Golia) üzerinde etkili olmamıştır.

\section{Hasat indeksi}

Hasat indeksi yönünden genotipler arasındaki farklar birinci ve ikinci yıl ile iki yıllık ortalamalara göre önemli bulunmuştur ( $P \leq 0.01)$. İlk yıl en yüksek hasat indeksleri Golia (\% 41.06) ve Seri-82 (\% 38.17) çeşitlerinden elde edilmiş ve diğer standart çeşit (Adana-99) ile aralarındaki fark önemli olmuştur. Yerel genotipler düşük hasat indeksine sahip olmuşlar, en düşük hasat indeksi (\% 19.97) Ziron Yazlığı-49 genotipinden elde edilmiştir. İkinci yıl, standart çeşitler 17 genotip içerisinde en yüksek hasat indeksine sahip olmuşlar ve kendi aralarındaki farklar önemli olmamıştır (Çizelge 8).

İki yıllık ortalamalara göre, Golia (\% 37.58) çeşidi ilk sıraya yerleşmiş, Seri-82 (\% 36.89) ile arasındaki fark önemsiz, Adana-99 ile arasındaki fark önemli olmuştur. Yerel genotiplerin hasat indeksi, standart çeşitlerden düşük olmuş ve en düşük hasat indeksi (\% 18.46) Ziron Yazlığı-49 genotipinden elde edilmiştir. Golia çeşidinin diğer iki standart çeşide göre oldukça kısa boylu olması, hasat indeksinin yüksek çıkmasında en önemli etmendir. Hasat indeksi bakımından çeşitler arasındaki farklılıkların bitki boylarındaki farklılıklardan ileri geldiği (Balkan ve Gençtan, 2008) toplam kuru madde üretimi ve asimilat dağılımındaki varyasyonların bir sonucu olarak, hasat indeksi yönünden genotipler arasında önemli farklılıkların olduğu belirlenmiştir (Koç ve Genç, 1990; Karimi ve Siddique, 1991). Araus ve ark. 
(2003), düşük kardeşlenme kapasitesine sahip çeşitlerin seçilmesiyle daha büyük başaklar elde edilebileceğini, oluşan çiçek sayısının azaltılması yoluyla da çiçek başına daha fazla asimilat sağlanması sonucunda hasat indeksinin artabileceğini belirtmiştir.

Birinci yıldaki elverişli iklim koşulları, daha yüksek hasat indeksi değerlerinin elde edilmesine fırsat sağlamıştır. İlk yıldaki yüksek yağışlar tüm genotiplerde hasat indeksinin yükselmesine neden olmuştur. Hasat indeksi yönünden ürün yıllarına göre önemli farkların ortaya çıktığı, kurak geçen ürün yıllarında tane dolum periyodunun kısalmasına bağlı olarak hasat indeksinin azaldığı (Gent ve Kiyomoto, 1992), hasat indeksi arttıkça tane veriminin yükseldiği (Kırtok ve Çölkesen, 1985) belirlenmiştir. Artan sıcaklığın tane verimi üzerindeki olumsuz etkisinin, biyomas üzerindeki etkiden fazla olduğu, tane dolum döneminde sıcaklıktaki $1^{\circ} \mathrm{C}$ lik artışın tane dolum süresini \% 5 kadar kısalttığı, hasat indeksi ve tane verimini oransal olarak azalttığı bildirilmiştir (Tansı, 2009).

Çizelge 8. Yerel ve standart ekmeklik buğday genotiplerinde tane verimi ve hasat indeksine ilişkin ortalama değerler

\begin{tabular}{|c|c|c|c|c|c|c|}
\hline \multirow{2}{*}{ Genotipler } & \multicolumn{3}{|c|}{ Tane verimi (kg/da) } & \multicolumn{3}{|c|}{ Hasat indeksi (\%) } \\
\hline & 1.Y.I** & 2. YוI** & Ort. ${ }^{* *}$ & 1.Y.I** & 2. Yil** & Ort. ${ }^{* *}$ \\
\hline Polatlı Yazlığı-4 & $329.3 c$ & $226.5 b$ & $277.9 \mathrm{bc}$ & $22.49 \mathrm{~cd}$ & $15.46 \mathrm{~b}$ & $18.97 \mathrm{de}$ \\
\hline Alabuğday-5 & $400.5 c$ & $291.0 \mathrm{~b}$ & $345.8 \mathrm{bc}$ & $24.25 \mathrm{c}$ & $18.69 \mathrm{~b}$ & $21.47 \mathrm{cde}$ \\
\hline Alabuğday-11 & $387.0 \mathrm{c}$ & $301.5 b$ & $344.3 \mathrm{bc}$ & $24.37 c$ & $21.11 b$ & $22.74 \mathrm{c}$ \\
\hline Ak Buğday-13 & $398.8 \mathrm{c}$ & $310.8 b$ & $354.8 \mathrm{~b}$ & $23.76 \mathrm{c}$ & $18.79 \mathrm{~b}$ & $21.28 \mathrm{cde}$ \\
\hline Nurhak Buğdayı-19 & $400.0 \mathrm{c}$ & $275.0 \mathrm{~b}$ & $337.5 \mathrm{bc}$ & $24.17 c$ & $17.76 \mathrm{~b}$ & $20.97 \mathrm{cde}$ \\
\hline Kırmızı Buğday-21 & $379.3 \mathrm{c}$ & $324.3 b$ & $351.8 \mathrm{bc}$ & $26.33 \mathrm{c}$ & $18.19 \mathrm{~b}$ & $22.26 \mathrm{~cd}$ \\
\hline Polatlı Yazlığı-24 & $350.0 \mathrm{c}$ & $235.0 \mathrm{~b}$ & $292.5 \mathrm{bc}$ & $24.35 \mathrm{c}$ & $17.08 \mathrm{~b}$ & 20.71 cde \\
\hline Beyaz Buğday-31 & $351.0 \mathrm{c}$ & $332.3 b$ & $341.6 \mathrm{bc}$ & $23.48 \mathrm{~cd}$ & $20.26 b$ & $21.87 \mathrm{cde}$ \\
\hline Elbistan Yazlığı-33 & $328.5 \mathrm{c}$ & $303.5 b$ & $316.0 \mathrm{bc}$ & $22.51 \mathrm{~cd}$ & $20.36 b$ & 21.43 cde \\
\hline Ofis Yazlığı-35 & $369.8 \mathrm{c}$ & $309.5 \mathrm{~b}$ & $339.6 \mathrm{bc}$ & $24.07 \mathrm{c}$ & $18.89 \mathrm{~b}$ & 21.48 cde \\
\hline Ankara Yazlığı-48 & $330.8 \mathrm{c}$ & $281.8 b$ & $306.3 \mathrm{bc}$ & $23.52 \mathrm{~cd}$ & $18.72 \mathrm{~b}$ & $21.12 \mathrm{cde}$ \\
\hline Ziron Yazlığı-49 & $302.3 \mathrm{c}$ & $233.0 \mathrm{~b}$ & $267.6 \mathrm{c}$ & $19.97 \mathrm{~d}$ & $16.95 b$ & $18.46 \mathrm{e}$ \\
\hline Yerli Buğday-50 & $348.5 \mathrm{c}$ & $269.5 \mathrm{~b}$ & $309.0 \mathrm{bc}$ & $24.73 c$ & $17.28 \mathrm{~b}$ & $21.00 \mathrm{cde}$ \\
\hline Göksun Buğdayı-51 & $390.3 \mathrm{c}$ & $268.3 b$ & $329.3 \mathrm{bc}$ & $24.13 c$ & $15.85 b$ & $19.99 \mathrm{cde}$ \\
\hline Adana-99 & $551.3 \mathrm{ab}$ & $655.5 \mathrm{a}$ & $603.4 \mathrm{a}$ & $33.49 \mathrm{~b}$ & $32.57 \mathrm{a}$ & $33.03 \mathrm{~b}$ \\
\hline Seri-82 & $616.8 \mathrm{a}$ & $654.0 \mathrm{a}$ & $635.4 \mathrm{a}$ & $38.17 \mathrm{a}$ & $35.61 \mathrm{a}$ & $36.89 a$ \\
\hline Golia & $512.3 b$ & $612.0 \mathrm{a}$ & $562.1 \mathrm{a}$ & $41.06 \mathrm{a}$ & $34.11 \mathrm{a}$ & $37.58 \mathrm{a}$ \\
\hline Ortalama & $396.8 \mathrm{a}$ & $346.1 \mathrm{~b}$ & 371.4 & $26.17 \mathrm{a}$ & $21.04 \mathrm{~b}$ & 23.60 \\
\hline
\end{tabular}

** $\mathrm{P}<0.01$ düzeyinde önemli

\section{incelenen özellikler arasındaki ilişkiler}

Incelenen özellikler arasındaki ilişkilere ait korelasyon katsayıları Çizelge 4.43 'de verilmiştir. Sapa kalkma başlangıcındaki yaprak alan indeksi ile; çiçeklenme dönemindeki anasap yaprak alanı arasında olumsuz ve önemli $\left(r=-0.68^{* *}\right)$ ilişki tespit edilmiştir.

Dört yapraklı dönemdeki özgül yaprak alanı ile; çiçeklenme dönemindeki yaprak alan indeksi arasında olumlu ve önemli $\left(r=0.61^{*}\right)$ ilişki belirlenmiştir. Özgül yaprak alanının artmasıyla yaprak alan indeksinin arttığı belirtilmiştir (Asseng ve ark., 2003).

Sapa kalkma başlangıcındaki özgül yaprak alanı ile; sapa kalkma başlangıcındaki anasap yaprak alanı ve dört yapraklı dönemdeki özgül yaprak alanı arasında olumlu ve önemli ilişki saptanmıştır. Çiçeklenme dönemindeki özgül yaprak alanı ile; sapa kalkma başlangıcındaki yaprak alan indeksi arasında olumlu ve önemli, çiçeklenme dönemindeki anasap yaprak alanı ve dört yapraklı dönemdeki özgül yaprak alanı arasında olumsuz ve önemli ilişkiler olmuştur.

Tane dolum periyodu ile; sapa kalkma başlangıcı ve çiçeklenme dönemindeki anasap yaprak alanı, dört yapraklı dönemdeki ve sapa kalkma başlangıcındaki özgül yaprak alanları arasında olumlu ve önemli; çiçeklenme dönemindeki özgül yaprak alanı arasında olumsuz ve önemli ilişki saptanmıştır.

Yaprak alan süresi ile; sapa kalkma başlangıcındaki ana sap yaprak alanı, çiçeklenme dönemindeki yaprak alan indeksi, dört yapraklı dönemdeki ve sapa kalkma başlangıcındaki özgül yaprak alanları ve tane dolum periyodu arasında olumlu ve önemli, çiçeklenme dönemindeki özgül yaprak alanı arasında olumsuz ve önemli ilişki ortaya çıkmıştır.

Olgunlaşma dönemi biyomas ile; çiçeklenme dönemindeki anasap yaprak alanı, tane dolum 
periyodu ve yaprak alan süresi arasında olumlu ve önemli, sapa kalkma başlangıcındaki yaprak alan indeksi, çiçeklenme dönemindeki özgül yaprak alanı arasında olumsuz ve önemli ilişki belirlenmiştir. Rebetzke ve Richards (1999), biyomas ile yaprak alanı arasında pozitif ilişkiler belirlemişlerdir. Ganguli ve ark. (1997) ve Öztürk ve Akten (1999) yaprak alan indeksi ile biyomas arasında önemli ilişkiler belirlerken, Reining (2002), kışlık buğdaylar üzerinde yaptığı bir çalışmada; ekimden hasata kadar geçen dönemin bütünü ile ele alındığında korelasyonun önemsiz $(r=0.01)$ olduğunu, oysa yaprak alan indeksi değerlerinin 34 arasında olduğu daha kısa bir dönemde ele alındığında biyolojik verim ile yaprak alan indeksi arasında önemli bir korelasyon olduğunu belirtmektedir. Biyomas ile özgül yaprak alanı arasında olumsuz ilişki olduğu belirtilmiştir (Richards, 2000).

Tane verimi ile; sapa kalkma başlangıcı ve çiçeklenme dönemindeki anasap yaprak alanı, dört yapraklı dönem ve sapa kalkma başlangıcındaki özgül yaprak alanları, tane dolum periyodu, yaprak alan süresi ve olgunlaşma dönemi biyomas arasında olumlu ve önemli ilişkiler belirlenmiştir. Tane verimi ile; sapa kalkma başlangıcı yaprak alan indeksi, çiçeklenme dönemindeki özgül yaprak alanı arasında olumsuz ve önemli ilişkiler ortaya çıkmıştır. Ashraf (2000), verimle yaprak alanının olumlu ve önemsiz ilişkili olduğu, yüksek yaprak alanına sahip genotiplerin yüksek tane verimine sahip olduğu belirtilmektedir (Duncan ve ark., 1981). Borojevic ve Williams (1982), Gebeyehou ve ark. (1982a), Gebeyehou ve ark. (1982b) ve Sharma (1994) gibi araştırıcılar, uzun tane dolum periyoduna sahip çeşitlerin yüksek verimli olduklarını belirterek, tane dolum periyodunun uzamasının çiçeklenme sonrası tozlanan çiçeklerde, kurumayı önlediğini ve olgunlaşmaya kadarki başakçık kayıplarını azaltarak, başaktaki tane sayısını ve dolayısıyla verimi artırdığını bildirmişlerdir. Borojevic ve Williams (1982), yaprak alan süresi ile tane verimi arasındaki ilişkilerin olumlu ve önemli olduğuna dikkat çeken araştırıcılar, yaprak alan süresinin uzatıımasının tane veriminin artırılmasında çok etkili bir faktör olduğunu vurgulamışlardır. Rana ve Sharma (1997), Reynolds ve ark. (2000), Shearman ve ark. (2005) ve Salvagiotti ve Miralles (2008), tane verimi ile biyomas arasında benzer şekilde olumlu ilişki olduğunu belirlemişlerdir. Buna karşılık Reynolds ve ark. (1999), Acreche ve ark. (2008), tane verimi ile biyomas arasında önemli bir ilişki olmadığı, Rees ve ark. (1993) ise ekmeklik buğdaylarda önemsiz, makarnalık buğdaylarda olumlu bir ilişki olduğu şeklinde sonuçlara varmışlardır. Öztürk ve Akten (1999), bizim bulgularımızın aksine yaprak alan indeksi ile tane verimi arasında önemli ilişkiler belirlemişlerdir.

Çizelge 9. İncelenen özellikler arası ilişkilere ait korelasyon katsayıları

\begin{tabular}{|c|c|c|c|c|c|c|c|c|c|c|c|}
\hline & 1 & 2 & 3 & 4 & 5 & 6 & 7 & 8 & 9 & 10 & 11 \\
\hline 1 & 1.00 & & & & & & & & & & \\
\hline 2 & 0.40 & 1.00 & & & & & & & & & \\
\hline 3 & -0.41 & $-0.68 * *$ & 1.00 & & & & & & & & \\
\hline 4 & 0.34 & -0.21 & -0.07 & 1.00 & & & & & & & \\
\hline 5 & 0.44 & 0.02 & -0.16 & $0.61^{*}$ & 1.00 & & & & & & \\
\hline 6 & $0.63^{* *}$ & 0.17 & -0.15 & 0.33 & $0.53^{*}$ & 1.00 & & & & & \\
\hline 7 & -0.37 & $-0.51^{*}$ & $0.58 *$ & -0.25 & $-0.51 *$ & -0.19 & 1.00 & & & & \\
\hline 8 & $0.69 * *$ & $0.58^{*}$ & -0.47 & 0.34 & $0.53^{*}$ & $0.59 *$ & $-0.65 * *$ & 1.00 & & & \\
\hline 9 & $0.59 *$ & 0.23 & -0.36 & $0.75 * *$ & $0.66 * *$ & $0.53^{*}$ & $-0.57^{*}$ & $0.80 * *$ & 1.00 & & \\
\hline 10 & 0.48 & $0.70 * *$ & $-0.67 * *$ & 0.27 & 0.15 & 0.10 & $-0.64 * *$ & $0.63^{* *}$ & $0.51^{*}$ & 1.00 & \\
\hline 11 & $0.58^{*}$ & $0.67 * *$ & $-0.57 *$ & 0.35 & $0.58^{*}$ & $0.52^{*}$ & $-0.80 * *$ & $0.90 * *$ & $0.70 * *$ & $0.69 * *$ & 1.00 \\
\hline 12 & $0.55^{*}$ & $0.59 *$ & $-0.50 *$ & 0.30 & $0.62 * *$ & $0.58^{*}$ & $-0.76 * *$ & $0.88 * *$ & $0.66 * *$ & $0.50 *$ & $0.97 * *$ \\
\hline
\end{tabular}

** $\mathrm{P}<0.01$ düzeyinde önemli, $* \mathrm{P}<0.05$ düzeyinde önemli. 1=sapa kalkma başlangıcındaki anasap yaprak alanı, 2=çiçeklenme dönemindeki anasap yaprak alanı, 3=sapa kalkma başlangıcındaki yaprak alan indeksi, 4=çiçeklenme dönemindeki yaprak alan indeksi, 5=dört yapraklı dönemdeki özgül yaprak alanı, 6=sapa kalkma başlangıcındaki özgül yaprak alanı, 7=çiçeklenme dönemindeki özgül yaprak alanı, 8=tane dolum periyodu, $9=y a p r a k$ alan süresi, 10=olgunlaşma dönemi biyomas, 11=tane verimi, 12=hasat indeksini göstermektedir.

Hasat indeksi ile; sapa kalkma başlangıcı ve çiçeklenme dönemindeki ana sap yaprak alanı, dört yapraklı dönem ve sapa kalkma başlangıcındaki özgül yaprak alanları, tane dolum periyodu, yaprak alan süresi, olgunlaşma dönemi biyomas ve tane verimi ile arasında olumlu ve önemli, sapa kalkma başlangıcındaki yaprak alan indeksi, çiçeklenme dönemindeki özgül yaprak alanı arasında olumsuz 
ve önemli ilişkiler bulunmuştur. Çizelge 9'da görüldüğü gibi ekmeklik buğday genotiplerinin hasat indeksi ile olgunlaşma dönemi biyomas arasında olumlu ve önemli ilişki belirlenmiştir. Öztürk ve Akten (1999) biyomas ile hasat indeksi arasında olumlu ilişki bulurken; Reynolds ve ark. (1997) biyomas ile hasat indeksi arasında olumsuz ilişki bulmuştur. Tane verimi ile hasat indeksi arasında olumlu ve önemli ilişki belirlenmiş olup, bulgularımız yapılan bazı araştırma sonuçları (Rana ve Sharma, 1997; Sayre ve ark., 1997; Reynolds ve ark., 1998; Acreche ve ark., 2008) ile uyuşurken, bazı araştırma sonuçları ile (Reynolds ve ark. 1997; Li ve ark., 2004) uyuşmamaktadır.

\section{Sonuç ve Öneriler}

Araştırma sonuçlarına göre yerel ekmeklik buğday genotipleri arasında fizyolojik özellikler yönünden önemli farklılıklar belirlenmiştir. Tane verimi yüksek genotiplerin geliştirilmesinde tane verimiyle olumlu ve önemli kararlı ilişkiye sahip olan sapa kalkma ve çiçeklenme dönemi ana sap yaprak alanı, dört yapraklı dönem ve sapa kalkma başlangıcı özgül yaprak alanları, tane dolum periyodu, yaprak alan süresi ve olgunlaşma dönemi biyomas özellikleride seleksiyon amacıyla kullanılabilir.

\section{Teşekkür}

$\mathrm{Bu}$ çalışma; Türkiye Bilimsel ve Teknolojik Araştırma Kurumu (TÜBITAK) tarafından 1060041 nolu proje kapsamında desteklenmiştir. Doktora tezinden derlenmiştir.

Çıkar Çatışması Beyanı: Makale yazarları aralarında herhangi bir çıkar çatışması olmadığını beyan ederler.

\section{Araştırmacıların Katkı Oranı Beyan Özeti:}

Yazarlar makaleye eşit oranda katkı sağlamış olduklarını beyan ederler.

\section{Kaynaklar}

Acreche, M. M., Briceno-Felix, G., Martin Sanchez, J. A., Slafer, G. A. 2008. Physiological bases of genetic gains in Mediterranean bread wheat yield in Spain. Europ. J. of Agronomy, 28(3): 162-170.

Aparıcio, N., Villegas, D., Casadesus, J., Araus, J.L., Royo, C. 2002. Relationship between Growth traits and spectral vegetation indices in durum wheat. Crop sci., 42: 15471548.

Araus, J. L.,, Bort, J., Steduto, P., Villages, D., Royo, C. 2003. Breeding cereals for Mediterranean conditions: ecophysiological clues for biotechnology application. Annals of Applied Biology, 142: 129-141.

Ashraf, M.Y. 2000. Genotypic variation for chlorophyll content and leaf area in wheat and their relation to grain yield. Wheat Information Service, 90: 42-44.

Asseng, S., Turner, N. C., Boturight, T., Condon, A. G. 2003. Evaluating the impact of a trait for increased spesific leaf area on wheat yields using a crop simulation model. Agronomy Journal, 95: 10-19.

Austin, R.B. 1982. Crop Characteristics and The Potential Yield of Wheat. J. of Agric. Sci., 98: 447-453.

Austin, R.B. Bingham J., Blackwell R.D., Evans L. T., Ford M. A., Morgan C. L., Taylor M., 1980. Genetic Improvements in winter wheat yields since 1900 and associated physiological changes. J. of Agric. Sci., 94: 675-689.

Austin, R.B. Ford, M. A., Morgan, C. L., 1989. Genetic improvement of winter wheat: A further evaluation. J. of Agric. Sci., 112: 295301.

Bahar, B., Yıldırım, M., Barutçular, C., Genç, i., 2008. Effect of Canopy temperature depression on grain yield and yield components in bread and durum wheat. Notulae Botanicae Horti Agrobotanici ClujNapoca, 36(1): 34-37.

Balkan, A., Gençtan, T. 2008. Bazı ekmeklik buğday (Triticum aestivum L.) Çeşitlerinde farklı sıra arası ve tohumluk miktarının tane verimi ve verim unsurlarına etkileri. Ankara Üniversitesi Tarım Bilimleri Dergisi, 14(1): 29-37.

Biesandz, A. 1990. Ein Beitrag zur Erforschung des Produktivitatstyps und der Qualitat van Durumveizen (Triticum turgidum con. Durum)- Untersuchungen an Türkischen Land- und Zuchsorten. Technische Universitat Berlin. D. 83, Nr. 124, 162 Seiten.

Bilgin, O., Korkut, K. Z. 2005. Bazı ekmeklik buğday (Triticum aestivum L.) çeşit ve hatlarının tane verimi ve bazı fenolojik özelliklerinin belirlenmesi. Tekirdağ Üniversitesi Ziraat Fakültesi Dergisi, 2(1): 58-65.

Borojevic, S., Williams, W. A. 1982. Genotype x environment interactions for leaf area parameters and yield components and their effects on wheat yield. Crop Sci., 22: 10201025.

Bruckner, P.L., Frohberg R.C. 1987. Stress tolerance and adaptation in spring wheat. Crop Sci., 27: 31-36. 
Casal, J. J., Aphalo, P. J., Sanchez, R. A. 1987. Phytochrome effects on leaf growth and chlorophyll content in Petunia axilaris. Plant Cell Environment, 10: 509-514.

Condon, A. G., Richards, R. A., Farquhar, G. D. 1993. Relationships between carbon isotope discrimination, water use efficiency and transpiration efficiency for drland wheat. Australian Journal of Agricultural Research, 44: 1693-1711.

Cox, T. S., Shroyer, J. P., Lui, B. H., Sears, R. G., Martin, T. J. 1988. Genetic improvement in agronomic traits of hard red winter wheat cultivars from 1919 to 1987. Crop Sci., 28: 756-760.

Cutforth, H. W., Campbell, C.A., Jame, Y. W., Clarke, J. M., Depauw, R. M. 1988. Growth Characteristics, yield components and rate of grain development of two high yielding wheats, HY320 and DT367, compared to two standart cultivars, Neepawa and Wakooma. Canada J. of Plant Sci., 68: 915928.

De Vita, P., Nicosia, O.L.D., Nigro, F., Platani, C., Riefolo, C., Fonzo, N.D., Cattivelli, L. 2007. Breeding progress in morpho-physiological, agronomical and qualitative traits of durum wheat cultivars released in Italy during the 20th century. Europ. J. of Agronomy, 26(1): 39-53.

Dreccer, M. F., Van Herwaarden, A. F., Chapman, S. C. 2009. Grain number and grain weight in wheat lines contrasting for stem water soluble carbohydrate concentration. Field Crops Research, 112: 43-54.

Duncan, R. R., Bockholt, A. J., Miller, F. R. 1981. Descriptive comparison of senescent and nonsenescent sorghum genotypes. Agronomy Journal, 73: 849-853.

Ferris, R., Ellis, R. H., Wheeler, T. R., Hadley, P. 1998. Effect of temperature stress at anthesis on grain yield and biyomass of field-grown crops of wheat. Annals of Botany, 82: 631-639.

Fischer, R. A., 1985. Numbers of kernels in wheat crops and the influence of solar radiation and temperature. J. of Agric. Sci., 100: 447461.

Friend, D. J. C. 1966. The Effects of Light and Temperature on the Growth of Cereals. in F.L. Milthorpe and J.D. Ivins, Eds. The Growth of Cereals and Grasses, Butterworths, London, UK, p. 181-199.

Ganguli, A. C., Mitchell, R. B., Wallace, M. C., Vermeire, L. T. 1997. Wildlife and Fisheries Management, Texas Tech University,
Department of Range, Lubbock, Texas, 79409-2125.

Gebeyehou, G., Knott, D. R., Baker, R. J. 1982a. Relationships among durations of vegetative and grain filling phases, yield components and grain yield in durum wheat cultivars. Crop Sci., 22: 287-290.

Gebeyehou, G., Knott, D. R., Baker, R. J. 1982 b. Rate and Duration of Filling in Durum Wheat Cultivars. Crop Sci., 22: 337-340.

Genç, i. 1977. Tahıllarda Tane Veriminin Fizyolojik ve Morfolojik Esasları. Ç.Ü. Ziraat Fak. Tarla Bitkileri Yetiştirme ve Islahı Bölümü Yayını, Adana.

Genç, i., Kıyomoto, R. K. 1992. Canopy photosynthesis and respiration in winter wheat adapted and unadapted to Connecticut. Crop Sci., 32(2): 425-431.

Genç, i. 1995. Canopy light interception, gas exchange, and biomass in reduced height isolines of winter wheat. Crop Sci., 35(6): 1636-1642.

Giunta, F., Motzo, R., Deidda, M. 1995. Effects of drought on leaf area development, biomass production and nitrogen uptake of durum wheat grown in a Mediterranean environments. Austr. J. of Agric. Res., 46: 99-111.

Giunta, F., Motzo, R., Pruneddu, G. 2008. Has longterm selection for yield in durum wheat also induced changes in leaf and canopy traits? Field Crops Research, 106(1): 68-76.

Gusta, L. V., Chen, T. H. 1987. The Physiology of Water and Temperature Stress. In: Wheat and Wheat Improvement, Agronomy Monogr, 13, Madison, WI.

Hafıd, R. E., Smith, D. H., Karrou, M., Samir, K. 1998. Morphological attributes associated with early-season drought tolerance in spring durum with in a Mediterranean enviromental. Euphytica, 101: 273-282.

Hotsonyame, G.K., Hunt, L.A. 1998. Seeding date, photoperiod and nitrogen effects on spesific leaf area of field-grown wheat. Can. J. Plant Sci., 77: 51-61.

Housley, T. L., Ohm, H. W. 1992. Earliness and duration of grain fill in winter wheat. Canadian J. of Plant Sci., 72: 35-48.

Hunt, L. A., Van Der Poorten, G., Pararajasingham, S. 1991. Postanthesis temperature effects on duration and rate of grain filling in some winter and spring wheats. Canadian J. of Plant Sci., 71: 609-617.

Jenner, C. F., Rathjen, A. J. 1975. Factors regulating the accumulation of starch in ripening wheat grain. Austr. J. Plant Physiol., 2: 311322. 
Karimi, M. M., Siddique, K. H. M. 1991. Crop growth and relative growth rates of old and modern wheat cultivars. Aust. J. Agric. Res., 42(1): 13-20.

Kınacı, E. 1993. Cumhuriyetten bugüne makarnalık buğday araştırmaları ve gelişmeler. Makarnalık Buğday ve Mamülleri Simpozyumu, s. 49-55.

Kırtok, Y., Çölkesen, M. 1985. Çukurova Koşullarında denemeye alınan arpa çeşitlerinde önemli bazı verim unsurları üzerinde path - katsayısı analizi. Doğa Bilim Dergisi, Cilt 9: 1.

Koç, M., Genç, i. 1990. Üç ekmeklik buğday genotipinde azot alımı ve azot hasat indeksi üzerinde araştırmalar. Turk. J. of Agric. and For., 14: 280-288.

Koç, M. Barutçular, C. 2000. Buğdayda çiçeklenme dönemindeki yaprak alanı indeksi ile verim arasındaki ilişkinin Çukurova koşullarındaki durumu. Turk. J. of Agric. and For., 24: 585593.

Kuşcu, A. 2006. Yazlık ekmeklik buğday (Triticum aestivum L.) Veriminde Son Çeyrek Yüzyılda Gerçekleşen İlerlemelerin Morfolojik ve Fizyolojik Esasları. Çukurova Üniv. Fen Bilimleri Enst., Doktora Tezi, Adana, (yayınlanmamış).

Li, F., Kang, S., Zhang, J. 2004. Interactive effects of elevated $\mathrm{CO}_{2}$, nitrogen and drought on leaf area, stomotal conductance, and evapotranspiration of wheat. Agricultural Water Management, 67: 221-233.

Liu, F., Stutzel, H. 2004. Biomass partitioning, spesific leaf area, and water use efficiency of vegetable amaranth (Amaranthus spp.) in response to drought stres. Scientia Horticulturae, 102: 15-27.

Lopez- Castaneda, C., Richards, R. A., Farquar, G. D. 1995. Variation in early vigor between wheat and barley. Crop Sci., 35: 472-479.

Loss, S. P., Siddique, K. H. M. 1994. Morphological and physiological traits associated with wheat yield increases in Mediterranean environment. Adv. Agronomy, 52: 229-276.

Mahler, R. L., Koehler, F. E., Lutcher, L. K. 1994. Nitrogen sourge, timing of application and placement: Effects on winter wheat production. Agron. Journal, 86: 637-642.

Major, D. J., Janzen, H. H., Sadasivaiah, R. S., Carefoot, J. M. 1992. Morphological characteristics of wheat associated with high productivity. Can. J. Plant Sci., 72: 689698.

Marcelis, L. F. M., Heuvelink, E., Goudriaan, J. 1998. Modelling biomass production and yield of horticultural Crops: A review. Scientia Horticulturae, 74: 83-111.

Monneveux, P., Rekika, D., Acevedo, E., Merah, O. 2006. Effect of drought on leaf gas exchange, carbon isotope discrimination, transpiration efficiency and productivity in field grown durum wheat genotypes. Plant Sci., 170: 867-872.

Moraques, M., Garcia Del Moral, L. F., Moralejo, M., Royo, C. 2006. Yield formation strategies of durum wheat landraces with distinct pattern of dispersal within the Mediterranean basin II. biomass production and allocation. Field Crops Research, 95: 182-193.

Olgun, M., Yıldırım, T., Partigöç, F. 1999. Doğu Anadolu Bölgesi'nde bazı buğday çeşitlerine ait çeşitli özelliklerin belirlenmesi. Orta Anadolu'da Hububat Tarımının Sorunları ve Çözüm Yolları Sempozyumu, s. 612-615, 811 Haziran 1999, Konya.

Öztürk, A. 1996. Ekim Sıklığı ve Azotun Kışlık Buğday Genotiplerinde Fotosentez Alımının Büyüklüğü ve Süresi ile Verim Üzerine Etkileri. Atatürk Üniversitesi Fen Bilimleri Enstitüsü Tarla Bitkileri Ana Bilim Dalı, Doktora Tezi, Erzurum, (yayınlanmamış).

Öztürk, A. Akkaya, A. 1996. Kışlık buğday genotiplerinde (Triticum aestivum L.) tane verimi, verim unsurları ve fenolojik dönemler üzerine bir araştırma. Atatürk Üniversitesi Ziraat Fakültesi Dergisi, 27(2): 187-202.

Öztürk, A. Akten, Ş. 1999. Kışlık buğdayda bazı morfofizyolojik karakterler ve tane verimine etkileri. Tr. J. of Agriculture and Forestry, 23: 409-422.

Öztürk, i., Gökkuş, A. 2008. Azotla gübrelemenin bazı ekmeklik buğday çeşitlerinin verimi ve kalitesine etkileri. Ankara Üniversitesi Ziraat Fakültesi Tarım Bilimleri Dergisi, 14(4): 334340.

Plaut, Z., Butow, B. J., Blumenthal, C. S., Wrigley, C. W. 2003. Transport of dry matter into developing wheat kernels and its contribution to grain yield under postanthesis water deficit and elevated temperature. Field Crops Research, 86(2-3): 185-198.

Puckridge, D. W. 1971. Photosynthesis of wheat under field conditions: Seasonal Trends in carbondioxide uptake of crop communities. Australian J. of Agric. Res., 22: 1-9.

Rana, V. K., Sharma, S. C. 1997. Correlation among some morpho-physiological characters associated with drought tolerance in wheat. Crop Improvement, 24(2): 194-198. 
Rana, J., Nagarajan, S. 2004. High temperature index for yield evaluation of heat tolerance in wheat varieties. Agricultural Systems, 79(2): 243-255.

Rawson, H. M., Gardner, P. A., Long, M. J. 1987. Sources of variation in spesific leaf area in wheat grown at high temperature. Australian Journal of Plant Physiology, 14: 287-298.

Rebetzke, G. J., Botwright, T. L., Moore, C. S., Richards, R. A., Condon, A. G. 2004. Genotypic Variation in spesific leaf area for genetic improvement of early vigour in wheat. Field Crops Research, 88: 179-189.

Rebetzke, G. J., Richards, R. A. 1999. Genetic improvement of early vigour in wheat. Australian Journal of Agricultural Research, 50: 291-301.

Rees, D., Sayre, K., Acevedo, E., Navas, T., Lu, Z., Zeiger, E., Limon, A. 1993. Canopy temperatures of wheat: Relationship with yield and potential as a technique for early generation selection. Wheat Special Report No. 10, 32 Pages, Mexico.

Reining, E. 2002. Leaf Area Indeks of Winter Wheat. Department of Use Systems and Landscape Ecology. http://z2.zalf.de/oa/lai_e.pdf

Reynolds, M. P, Nagarajan, S., Razzaque, M. A., Ageeb, O. A. A. 1997. Using Canopy Temperature Depression to Select for Yield Potential of Wheat in Heat-Stressed Environments. Wheat Special Report, No:42, CIMMYT, Mexico.

Reynolds, M. P, Singh, R.P., Ibrahim, A., Ageeb, O. A. A., Larqué-Saavedra, A., Quick, J. S. 1998. Evaluating physiological traits to complement empirical selection for wheat in warm environments. Euphytica, 100: 8495.

Reynolds M. P, Rejeram S., Sayre K. D. 1999. Physiological and genetic changes of irrigated wheat in the post-green revolution period and approaches for meeting projected global demand. Crop Sci., 39: 1611-1621.

Reynolds, M. P, Delgado, Mi. B., GutierrezRodriguez, M., Larque-Saavedra, A. 2000. Photosynthesis of wheat in a warm, irrigated environment - I: Genetic diversity and crop productivity. Field Crops Research, 66(1): 37-50.

Reynolds, M. P, 2002. Physiological Approaches to Wheat Breeding. In B. C. Curtis, S. Rajaram, H. Gómez Macpherson, eds. Bread Wheat Improvement and Production, FAO Plant Production and Protection Series. No. 30.
Richards, R. A. 1983. Manipulation of leaf area and its effect on grain yield in droughted wheat. Australian J. of Agric. Res., 34: 23-31.

Richards, R. A., 1996a. Defining selection criteria to improve yield under drought. Planth Growth Reulation, 20: 157-166.

Richards, R. A., 1996b. Increasing yield potential in wheat-source and sink limitations. In increasing yield potential in wheat: Breaking the Barriers (Eds. M.P. Reynolds, Rajaram, S., McNab, A.), pp. 134-149.

Richards, R. A., 2000. Selectable traits to increase crop photosynthesis and yield of grain crops. Journal of Experimental Botany, 51: 447-458.

Salvagiotti, F., Miralles, D .J. 2008. Radiation interception, biomass production and grain yield as affected by the interaction of nitrogen and sulfur fertilization in wheat. Europ. J. of Agronomy, 28: 282-290.

Savin, R., Slafer, G. A. 1991. Shading effects on the yield of an Argentinian wheat cultivar. J. of Agricultural Sci., 116: 1-7.

Sayre, Kd., Rajaram, S., Fischer, R. A. 1997. Yield potential progress in short bread wheats in Northwest Mexico. Crop Sci., 37: 36-42.

Sharma, R. C. 1994. Early generation selection for grain filling period in wheat. Crop Sci., 34: 945-948.

Shearman, V. J., Sylvester-Bradley, R., Scott, R. K., Foulkes, M. J. 2005. Physiological processes associated with wheat yield progress in the UK. Crop Sci., 45(1): 175-185.

Shuting, D., 1994. Canopy apparent photosynthesis, respiration and yield in wheat. J. of Agric. Sci., Camb., 122: 7-12.

Siddique, K. H. M., Kirby, E. J. M., Perry, M. W. 1989a. Ear: stem ratio in old and modern wheat varieties; relationship with improvement in number of grains per ear and yield. Field Crops Reserach, 21: 59-78.

Siddique, K. H. M., Belford, R. K., Perry, M. W., Tennant, D. 1989b. Growth, development and light interception of old and modern wheat cultivars in a Mediterranean-type environment. Aust. J. of Agric. Res., 40: 473487.

Slafer, G. A., Andrade, F. H. 1993. Physiological attributes related to the generation of grain yield in bread wheat cultivars released at different eras. Field Crop Research, 31: 351367.

Slafer, G. A., Araus, J. L., Richards, R.A. 2000. Physiological Traits That Increase the Yield Potential of Wheat, Wheat Ecology and Physiology of Yield Determination, Ed: 
Satorre, E.H., Slafer, G.A., Food Products Press, New York, pp. 379.

Spiertz, J. H. J., Hag, B. A., Kupers, L. J. P. 1971. Relation between Green area duration and grain yield in some varieties of spring wheat. Neth., J. Agric. Sci., 19: 211-222.

Spiertz, J. H. J., Vos, J. 1985. Grain Growth of Wheat its Limitation by Carbonhydrate and Nitrogen Supply. In Wheat Growth and Modelling, Plenum Press, New York, 407.

Steduto, P., Alvino, A., Magliulo, V., Sisto, L. 1986. Analysis of the Physiological and Reproductive Responses of Five Wheat Varieties under Rainfed and Irrigated Conditions in Southern Italy. Drought Resistance in Plants: 131-149, Meeting Held in Amalfi, 19-23 October 1986, Belgium.

Tansı, V. 2009. İklim Değişimine Bitki Ekosistem Tepkimeleri: Buğday http://www.angelfire.com/vt2/veyis/kitap/ bugday.

Tashiro, T., Wardlaw, I. F. 1990. The response to high temperature shock and humudity changes prior to and during the early stages of grain development in wheat. Australian Journal of Plant Physiology, 17: 551-561.

Tiryakioğlu, M. 2004. Çukurova Bölgesi Güncel Ekmeklik Buğday (Triticum aestivum L.) Çeşitlerinde Verim Oluşumuna Etkili MorfoFizyolojik Karakterler Üzerine Araştırmalar. Çukurova Üniv. Fen Bilimleri Enst., Doktora Tezi, Adana, (yayınlanmamış).

Tiryakioğlu, M. Koç, M. 2007. Çukurova bölgesi güncel ekmeklik buğday (Triticum aestivum L.) çeşitlerinde verim oluşumu: I. yapraklardaki yaşlanma unsurlarının verimle ilişkisi. Türkiye VII. Tarla Bitkileri Kongresi, 25-27 Haziran 2007, Erzurum, s. 55-58.

Waddington, S. R., Ransom, J. K., Osmanzai, M., Saunders, D. A. 1986. Improvement in the yield potential of bread Wheat adapted to Northwest Mexico. Crop Sci., 26: 698-703.

Wardlaw, I. F., Dawson, I. A., Munibi, P., Fewster, R. 1989. The tolerance of wheat to high temperatures during reproductive growth. I Survey Procedures and General Response Patterns. Aust. J. Agric Res., 40: 1-13.

Warrington, I. J., Dunstone, R. L., Green, L. M. 1977. Temperature effects at three development stages on the yield of the wheat ear. Australian Journal of Agricultural Research, 28: 11-27.

Wiegand, C. L., Gebermann, A. H., Cuellar, J. A. 1981. Development and yield of hard red winter wheats under semitropical conditions. Agronomy Journal, 73(1): 29-37.

Woodruft, D.R., Tonks, J. 1983. Relationship between time of anthesis and grain yield of wheat genotypes with differing developmental patterns. Australian J. of Agric. Res., 34: 1-11.

Zencirci, N., Aktan, B., Atlı, A. 1993. Türkiye makarnalık buğday yerel çeşitlerinin genetik zenginliğinin modern çeşitlere katkısı. Makarnalık Buğday ve Mamülleri Simpozyumu, s. 107-112.

Zhang, J., Sui, X., Li, B., Su, B., Li, J., Zhou, D. 1998. An improved water-use efficiency for winter wheat grown under reduced irrigation. Field Crops Research, 59: 91-98. 